\title{
Pituitary Control of BK Potassium Channel Function and Intrinsic Firing Properties of Adrenal Chromaffin Cells
}

\author{
Peter V. Lovell and David P. McCobb \\ Department of Neurobiology and Behavior, Cornell University, Ithaca, New York 14853
}

The discovery that the hypothalamic-pituitary-adrenocortical (HPA) endocrine stress axis controls an alternative splicing decision in chromaffin Slo-encoded BK (big potassium) channels raised the possibility that activation of the HPA could serve as a mechanism to tune the intrinsic electrical properties of epinephrine-secreting adrenal chromaffin cells. To test this, we compared BK functional properties and cell excitability in chromaffin cells from normal and hypophysectomized (pituitaryablated) rats. Hypophysectomy was found to alter the voltage dependence and kinetics of BK gating, making channels less accessible for activation from rest. Perforated-patch recordings revealed changes in action potential waveform and repetitive firing properties. The maximum number of spikes that could be elicited with a 2 sec depolarizing current pulse was reduced by $\sim 50 \%$ by hypophysectomy. The results indicate that pituitary hormones can adapt the mechanics of adrenal catecholamine release by tailoring BK channel function.

Key words: hypophysectomy; BK channels; chromaffin cells; action potentials; adrenal medulla; catecholamines; stress
Descending synaptic input to adrenomedullary chromaffin cells triggers the rapid release of adrenaline, or epinephrine, by eliciting $\mathrm{Na}^{+}$and $\mathrm{Ca}^{2+}$ channel-dependent action potentials. Thus the intrinsic excitable properties of chromaffin cells, by defining action potential responses, play perhaps as great a role in limiting or patterning epinephrine secretion as does the input. In chromaffin cells, a significant fraction of the outward current gated at physiological voltages is carried by $\mathrm{BK}$ (big $\mathrm{K}^{+}$) voltage- and $\mathrm{Ca}^{2+}$-activated potassium channels, leading several investigators to argue that BK channels play a central role in shaping intrinsic excitability, particularly with respect to repetitive firing (Solaro et al., 1995; Lingle et al., 1996; Lovell et al., 2000). Recent evidence that pituitary stress hormones influence alternative splicing of Slo gene-encoded BK channels has raised the hypothesis that stressrelated activation of the hypothalamic-pituitary-adrenocortical (HPA) axis may dynamically control the character of autonomic crisis responses by tuning chromaffin cell excitability (Xie and McCobb, 1998). To explore this, we have characterized changes in chromaffin cell function resulting from the surgical elimination of the HPA hormone cascade by hypophysectomy.

Hypophysectomy eliminates the source of adrenocorticotropic hormone (ACTH), thereby dramatically and irreversibly reducing serum corticosterone levels to the margin of detectability by radioimmunoassay. One consequence is a precipitous decline in the adrenal transcription of the enzyme phenylethanolamine- $N$ methyltransferase (PNMT), which catalyzes the conversion of norepinephrine to epinephrine (Stachowiak et al., 1988; Viskupic

\footnotetext{
Received Dec. 22, 2000; revised Feb. 28, 2001; accepted March 2, 2001.

This work was supported by a grant from the American Heart Association and National Institutes of Health to D.P.M. P.V.L. was supported by National Institute of Mental Health Training Grant MH15793. We thank Drs. Ron Harris-Warrick, Jason MacLean, and Bruce Johnson for many helpful discussions and critical reading of this manuscript; D. G. James, A. Thabet, J. O'Brien, A. Gersten, and the Cornell Veterinary Diagnostic Laboratories for technical assistance; and P. Zeller and S. Mahmoud for assistance with the computer simulations.

Correspondence should be addressed to Dr. David P. McCobb, Department of Neurobiology and Behavior, W153 Mudd Hall, Cornell University, Ithaca, NY 14853. E-mail: dpm9@cornell.edu.

Copyright (c) 2001 Society for Neuroscience $\quad 0270-6474 / 01 / 213429-14 \$ 15.00 / 0$
}

et al., 1994). That this reflects a dynamic and bidirectional influence of the HPA on epinephrine synthesis is supported by behavioral experiments (Stachowiak et al., 1988; Wong et al., 1992; Baruchin et al., 1993; Lemaire et al., 1993; Betito et al., 1994; Viskupic et al., 1994; Wong et al., 1995). In parallel with the drop in PNMT transcription, hypophysectomy also alters the relative abundance of two splice variants of Slo (Xie and McCobb, 1998). Thus at one splice site in the large C-terminal domain, the optional inclusion of the $174 \mathrm{bp}$ stress axis-regulated exon (STREX) is progressively reduced. Injection of exogenous ACTH after hypophysectomy prevents this decline, thus implicating the stress-related, corticotrope subfunction of the pituitary (Xie and McCobb, 1998).

Xenopus oocyte expression studies suggest important functional consequences for the hormonal regulation of Slo splicing. The presence of the optional STREX in a Slo cRNA construct expressed in an oocyte results in a negative shift in the voltage dependence of channel activation, when compared with the otherwise identical ZERO construct (lacking STREX). At a given voltage and calcium concentration, the rates of activation and deactivation are increased and decreased by STREX, as if its presence stabilizes the open state of the channel.

The prominence of BK current in chromaffin cells suggests that changes in BK properties resulting from hypophysectomy are likely to alter cellular excitability. The results described in this report are consistent with the idea that pituitary function exerts a dynamic, regulatory control over the excitable properties of adrenal chromaffin cells by altering the gating of BK channels, with probable ramifications for autonomic function and pathology.

\section{MATERIALS AND METHODS}

Chromaffin cell dissociation and culture. The techniques used in the isolation and culturing of chromaffin cells closely followed those described by Lovell et al. (2000). Hypophysectomies (surgical ablation of the pituitary gland) were performed $5-6$ weeks postpartum by aspiration of the pituitary tissue exposed by trephination at the occipitosphenoid suture, accessed via the parapharyngeal approach. Hypophysectomy was confirmed before cell dissociation by comparison of body weights with those of unoperated animals of the same age and source (Charles River 
Laboratories, Wilmington, MA). Hypophysectomized rats received a $5 \%$ sucrose supplement. Adrenomedullary tissue from the glands of hypophysectomized (hypox; $n=24$ ) and unoperated (normal; $n=21$ ) Sprague Dawley rats was surgically isolated, minced, washed repeatedly in sterile HBSS (Life Technologies, Gaithersburg, MD), and incubated for $60 \mathrm{~min}$ with gentle agitation in a collagenase B solution (Boehringer Mannheim, Indianapolis, IN; $1.5 \mathrm{mg} / \mathrm{ml}$ in HBSS), $\mathrm{pH} 7.0$, at $37^{\circ} \mathrm{C}$. Extracted tissue was then washed repeatedly in a $\mathrm{Ca}^{2+}$ - and $\mathrm{Mg}^{2+}$-free HBSS (Life Technologies) and incubated for $30 \mathrm{~min}$ at $37^{\circ} \mathrm{C}$ in a solution containing trypsin (Life Technologies; $0.125 \%$ in $\mathrm{Ca}^{2+}$ - and $\mathrm{Mg}^{2+}$-free HBSS). Chromaffin cells were freed from clumps by repeated trituration through fire-polished Pasteur pipettes and suspended in a preincubated $\left(37^{\circ} \mathrm{C}\right)$ sterile culture medium (Life Technologies; RPMI 1640 with $10 \%$ horse serum, $5 \%$ fetal calf serum, $2 \mathrm{U} / \mathrm{ml}$ penicillin-G, $2 \mu \mathrm{g} / \mathrm{ml}$ streptomycin sulfate, and $100 \mathrm{U} / \mathrm{ml}$ nystatin). Cells were aliquoted $(100 \mu \mathrm{l})$ in the center of $15 \mathrm{~mm}$ glue rings in $35 \mathrm{~mm}$ sterile plastic dishes (Falcon 3001; Fisher Scientific, Pittsburgh, PA) coated with collagen (Vitrogen, Collagen Corporation, Carlsbad, CA; $0.6 \mathrm{mg} / \mathrm{ml}$ dilution in sterile $\mathrm{ddH}_{2} \mathrm{O}$ ) or poly-D-lysine (Sigma, St. Louis, $\mathrm{MO} ; 0.01 \%$ in $\mathrm{ddH}_{2} \mathrm{O}$ ). Cell cultures were maintained in a $5 \% \mathrm{CO}_{2}$ atmosphere at $37^{\circ} \mathrm{C}$ and used over a period of 1-4 d. Culture medium was changed as needed.

Staining of tissue sections and isolated chromaffin cells. Dissociated cells were washed several times in a $P B S$ containing bovine serum albumin (BSA; 0.1\%; Life Technologies) and fixed for $60 \mathrm{~min}$ in a paraformaldehyde solution (PFA; 4\% in PBS). Cells were washed a second time in PBS with BSA and permeabilized for $10 \mathrm{~min}$ in a Triton X-100 solution at room temperature (0.2\% Triton X-100 in PBS; Fisher Scientific). Cells were then incubated overnight with primary antibodies directed against PNMT (Diasorin, Stillwater, MN) and tyrosine hydroxylase (TH; Sigma). The following day, cells were washed several times with PBS and incubated for $1 \mathrm{hr}$ with Texas Red and fluorescein secondary antibodies (Vector Laboratories, Burlingame, CA). Cell staining was observed with a Nikon Eclipse E600-FN scope and imaged using a Spot (Diagnostic Instruments) camera and Spot 2.2 software. For adrenal sections, PFAperfused glands were embedded in paraffin, sectioned, mounted, and stained with hematoxylin and eosin.

Electrophysiological methods. Macroscopic BK currents (0.1-1 nA) were recorded from inside-out and outside-out patches using standard patch-clamp recording techniques as described by Hamill et al. (1981) and Sakmann and Neher (1985). Patches were excised from cultured chromaffin cells using standard borosilicate electrodes (World Precision Instruments, Sarasota, FL; inside-outside diameter, 1.12-1.5 mm) pulled to resistances of 2-4 M $\Omega$ and coated with Sylgard 184 (Dow Corning, Midland, MI) to reduce electrode capacitance. All patch experiments were performed at room temperature $\left(22.5^{\circ} \mathrm{C}\right)$ in symmetrical $\left[\mathrm{K}^{+}\right]$ recording solutions designed to eliminate the driving force on potassium and permit any DC offset to be canceled at $0 \mathrm{mV}$. For inside-out patches, high-resistance seals $(2-4 \mathrm{G} \Omega)$ were achieved with a gentle suction and with patches pulled rapidly in $\mathrm{Ca}^{2+}$-free saline. Currents were recorded with a List EPC-7 patch-clamp amplifier (Heka Electronik, Lambrecht, Germany), Bessel high-pass filtered at $10 \mathrm{kHz}$, digitally converted with an ITC-16 analog-to-digital (Instrutech Corporation, Great Neck, NY), and stored on a Macintosh Power personal computer 8100/80 using the Pulse 8.02 software package (Heka, Lambrecht, Germany).

For whole-cell recording of calcium currents, standard patch-clamp recording techniques were used. Chromaffin cells were typically held at $-70 \mathrm{mV}$, and the voltage dependence of calcium currents was measured by a series of increasing voltage steps ( $I-V$ plots). The effect of calcium channel rundown was minimized by using an intersweep interval of at least $10 \mathrm{sec}$, and every effort was made to finish experiments 10 min after achieving whole-cell access. To investigate the effect of the action potential (AP) waveform on calcium influx, a series of action potential waveform templates (APWs) was used. APWs consisted of a set of two APs varying in amplitude, half-amplitude duration, and afterhyperpolarization (AHP) magnitude (the third spikes from normal and hypox spike trains) and a second set of spike trains varying in spike number and frequency. The APW baselines were set to a resting potential of $-70 \mathrm{mV}$ and delivered as standard voltage-clamp pulses. Inverted, one-quarterscale waveforms were also presented to determine appropriate values for off-line leak subtraction. A measure of the effect of APWs on calcium entry was determined by calculating the proportion $(\mathrm{nCS} / \mathrm{hCS}$ ) of the integrated area under the normal calcium spike (nCS) as a function of that measured for the hypox calcium spike (hCS).

For perforated-patch recordings, high-resistance seals were achieved as described above, and recordings were made in current-clamp mode when the apparent input resistance had dropped to values between 50 and $150 \mathrm{M} \Omega$. Wherever necessary, a small holding current was used to maintain the resting potentials between -65 and $-75 \mathrm{mV}$. Previous studies indicated that many cells recorded in whole-cell mode exhibited little or no repetitive firing capabilities. Much greater repetitive firing was observed in perforated-patch mode. The reduced firing may be caused by the buffering of cytoplasmic $\left[\mathrm{Ca}^{2+}\right]$ by EGTA internally perfused through the recording electrode. To verify that the perforated patch was not ruptured during recording, input resistance was monitored during deliberate rupture at the end of the recording. For excitability measurements, a series of $2 \mathrm{sec}$ current pulses of increasing strength was used to elicit repetitive firing. The magnitude of current and serial increment of steps was adjusted by trial and error to fit the varying input resistances of the cells. For pharmacology, cells were exposed to bathapplied $1 \mathrm{~mm}$ tetraethylammonium (TEA) as described below for voltage clamp.

Solutions. For all solutions, osmolarity was measured by dew point osmometry and adjusted to within $3 \%$ of 300 Osm. For consistency, all comparative characterizations of BK properties that are described, except where indicated, used a single solution made up once in large volume and stored in frozen aliquots. This solution, which was used in both the electrode and bath, contained the following: $160 \mathrm{mM} \mathrm{KCl}, 10$ mM HEPES, and no added calcium. The $\mathrm{pH}$ was adjusted with $\mathrm{KOH}$ to 7.4. The free-calcium concentration $(\sim 1 \mu \mathrm{M})$, estimated previously at $\sim 6$ $\mu \mathrm{M}$ (Lovell et al., 2000) using a $\mathrm{Ca}^{2+}$ ion-selective electrode, was more accurately determined using a Fura-6F (Molecular Probes, Eugene, OR) ratiometric calcium indicator calibrated against a calcium buffer series (kit 2; Molecular Probes) and measured with an SLM-Aminco 8000c spectrofluorimeter (Spectronic Unicam, Rochester, NY). In the indicated experiments, an additional $\mathrm{KMeSO}_{3}$-based saline was used that contained (in mM): $140 \mathrm{KMeSO}_{3}, 20 \mathrm{KOH}, 10 \mathrm{HEPES}, 5$ HEDTA, and $1.865 \mathrm{Ca}\left(\mathrm{MeSO}_{3}\right)_{2} ; \mathrm{pH}$ was adjusted to 7.4 with $5 \% \mathrm{MeSO}_{3}$ to make a solution calculated to have a free-calcium concentration of $4 \mu \mathrm{M}$. A zero-calcium solution was made by adding EGTA $(1.9 \mathrm{mg} / \mathrm{ml}$; Sigma) to the $\mathrm{KMeSO}_{3}$-based saline. Bath-applied solutions were delivered with a seven-barrel, gravity-fed perfusion system. All other solutions, TEA ${ }^{+}(1$ $\mathrm{mm}$; ICN Biomedicals, Aurora, OH) and charybdotoxin (CTX; $10 \mathrm{~nm}$; Alomone Labs, Jerusalem, Israel), were made in the stock $1 \mu \mathrm{M}\left[\mathrm{Ca}^{2+}\right]$ recording saline, and $\mathrm{pH}$ was adjusted to 7.4 .

Whole-cell calcium currents were recorded in voltage clamp using a bath-perfused CsCl-based rodent Ringer's solution containing the following (in mM): $2 \mathrm{CaCl}_{2}, 10 \mathrm{HEPES}$, and $150 \mathrm{TEAOH} ; \mathrm{pH}$ was adjusted to 7.4 with $\mathrm{HCl}$. For pharmacology, $100 \mu \mathrm{M}$ cadmium and $1 \mu \mathrm{M}$ tetrodotoxin were added directly to the Ringer's solution, and $\mathrm{pH}$ was adjusted to 7.4. The pipette solution contained the following (in $\mathrm{mM}$ ): 140 $\mathrm{CsCl}, 5 \mathrm{MgCl}_{2}$, and 10 EGTA (free acid); $\mathrm{pH}$ was adjusted to 7.4 with CsOH. ATP (1 mm ATP-Mg) and GTP (0.1 mm GTP-Li) were added to the pipette saline to reduce calcium channel rundown. Every effort was made to finish current recordings within $10 \mathrm{~min}$ of achieving the wholecell recording configuration.

For current-clamp recordings, the bath solution contained the following (in mM): $145 \mathrm{NaCl}, 5 \mathrm{KCl}, 10 \mathrm{HEPES}, 2 \mathrm{CaCl}_{2}$, and $1 \mathrm{MgCl}_{2} ; \mathrm{pH}$ was adjusted to 7.4 with $2 \mathrm{M} \mathrm{NaOH}$. For pharmacology, TEA ${ }^{+}(1 \mathrm{~mm})$ or CTX (10 nM) was added directly to the Ringer's solution, $\mathrm{pH}$ was adjusted to 7.4 , and the bath was perfused. The technique used to obtain perforated patches closely followed procedures described by Herrington et al. (1995). The tip of a patch electrode (2-4 M $\Omega$ ) was first filled with whole-cell saline containing (in $\mathrm{mM}$ ): $140 \mathrm{KCl}, 5 \mathrm{MgCl}_{2}, 10 \mathrm{EGTA}$, and 10 HEPES, $\mathrm{pH}$ 7.4. The electrode barrel was then backfilled with a solution containing $20 \mu \mathrm{l}$ of fresh stock Amphotericin B $(6 \mathrm{mg} / 100 \mu \mathrm{l}$ of DMSO; Life Technologies) and $40 \mu \mathrm{l}$ of stock Pluronic acid F-127 (2.5 $\mathrm{mg} / 100 \mu \mathrm{l}$ of DMSO; Molecular Probes) added to $1 \mathrm{ml}$ of whole-cell recording saline. To maintain perforating efficacy, fresh aliquots were used for each hour of recording. Every effort was made to achieve rapid seals with resistances of 1-2 G $\Omega$ shortly after the electrodes were filled.

Voltage-clamp analysis of BK properties. Analysis of current and voltage data was performed off-line using custom-written software for Igor Pro (Wavemetrics, Lake Oswego, OR). Single channel and multichannel (5-30 channels) clamp data were averaged, linear leak was subtracted, and various kinetic and steady-state parameters were measured. The fraction of total current that was inactivated after a $350 \mathrm{msec}\left(\mathrm{BK}_{\mathrm{i}} /\right.$ $\mathrm{BK}_{\text {total }}$ ) step to $+80 \mathrm{mV}$ was determined by calculating the proportion of current present at the end of a $350 \mathrm{msec}$ step as a function of the estimated peak current. Measurements of the time constant for current decay, activation, and inactivation were estimated by fitting at least $70 \%$ 
of the waveform with a Levenburg-Marquardt least-squares search algorithm for single-exponential equations. The calcium dependence and voltage dependence of both activation and inactivation were estimated by measuring the peak conductance of traces activated at increasingly positive test potentials. The voltage of half-activation $\left(V_{0.5}\right)$, maximum conductance, and slope conductance were calculated by fitting conductance versus voltage plots $(G-V)$ with a single Boltzmann equation of the form:

$$
G_{V_{\mathrm{m}}}=\frac{G_{\max }}{1+\mathrm{e}^{\left(V_{\mathrm{m}}-\left(V_{0.5} / s\right)\right)}},
$$

where $s$ is the slope in millivolts per exponential-fold change in conductance and $V_{0.5}$ is the voltage of half-activation. Properties of BK channel gating measured from hypox and normal rats were compared using a Mann-Whitney test for mean differences $(\alpha=0.05)$.

Current-clamp analysis of excitability. For each trace in an $I-V$ series, several features of both the spike train and individual action potential waveforms were measured. The maximum number of spikes elicited by a $2 \mathrm{sec}$ depolarizing pulse was characterized. For each of the first three spikes in a trace, the peak-to-trough amplitude (positive peak of the AP to minimum trough of the AHP), the half-amplitude spike duration (time elapsed between the half-amplitude coordinates for the rising and falling phase of the AP), and the magnitude of the AHP (minimum voltage of the AHP minus the baseline voltage) were measured. Peak-to-trough voltage, half-amplitude duration, AHP voltage, and maximum spike number values were averaged and compared using a Student's $t$ test for mean differences $(\alpha=0.05)$

Mathematical modeling of cellular excitability. All simulations were performed using Nodus modeling software (De Schutter, 1989) on a Power Macintosh 7100/80 computer. The model consisted of a spherical cell $(20 \mu \mathrm{m}$ in diameter) with a passive specific membrane resistance of $40 \mathrm{k} \Omega / \mathrm{cm}^{-1}$, specific capacitance of $1 \mu \mathrm{F} / \mathrm{cm}^{2}$, and cytoplasmic resistivity of $200 \Omega / \mathrm{cm}^{-1}$. Active membrane properties included three voltagegated ionic currents (equations in the Appendix) simulated by standard Hodgkin and Huxley equations (Hodgkin and Huxley, 1952). These included a fast-inactivating sodium conductance [modeled after Hodgkin and Huxley (1952)], a standard leak current, and one of two noninactivating voltage-gated potassium channels. The potassium conductances were calcium insensitive and identical in every way except in their voltage dependence of half-activation $\left(V_{0.5}=20 \mathrm{vs} 40 \mathrm{mV}\right)$. To evaluate firing behavior during current injection, the following equation was solved for membrane potential $\left(V_{\mathrm{m}}\right)$ :

$$
C_{\mathrm{m}} \frac{\mathrm{d} V_{\mathrm{m}}}{\mathrm{d} t}=\frac{V_{\mathrm{m}}-E_{\mathrm{R}}}{R_{\mathrm{L}}}+\sum_{\text {ion }} g_{\text {ion }}\left(V_{\mathrm{m}} \cdot t\right)\left(V_{\mathrm{m}}-E_{\text {ion }}\right)+I_{\text {inj }},
$$

where $C_{\mathrm{m}}$ is total capacitance, $E_{\mathrm{R}}$ is the resting membrane potential, $g_{\text {ion }}$ is the conductance for any given channel in the cell, $t$ is time, $E_{\mathrm{ion}}$ is the equilibrium potential for each ion, $R_{\mathrm{L}}$ is the inverse of the passive leak conductance, and $I_{\text {inj }}$ is the magnitude of the current injection step. The first term in Equation 2 describes the passive leak current; the second term represents the sum of the voltage-dependent ionic currents. The total somatic resistance is given by:

$$
R=\pi D^{2} R_{\mathrm{m}} \Omega,
$$

where $D=10 \mu \mathrm{M}$. To estimate the change in voltage as a function of time during current injection, Equation 2 was integrated using the Fehlberg method (Forsythe et al., 1977) with a fixed time step $(\triangle t=0.05 \mathrm{msec})$ described by the equation:

$$
V_{\mathrm{m}}=V_{0}+\Delta t \frac{\delta V_{0}}{\delta t}
$$

where $V_{0}$ is the initial membrane voltage. In current-clamp simulation, spike trains were elicited from the two model cells by 1 sec squarecurrent injection steps. Direct comparisons of cellular excitability were made by enumerating the spikes elicited during the depolarizing pulse for each of the cells at the same level of current injection. Voltage-clamp analysis of the steady-state parameters of the potassium currents was made using voltage-clamp protocols like those described above for BK channels.

\section{RESULTS}

\section{Chromaffin cells from hypophysectomized rats}

Chromaffin cells were isolated from rats between 2 and 6 months after hypophysectomy and compared with cells isolated from unoperated rats from the same cohort. Successfully hypophysectomized rats were readily distinguished from unoperated rats and the very few rats that were incompletely hypophysectomized by their small size $(162 \pm 23.8$ vs $530 \pm 248 \mathrm{gm})$ and finer, softer, and whiter fur. Paraffin sections from normal and hypox adrenals stained with hematoxylin and eosin illustrate differences in cortical and medullary tissues (Fig. $1 A, B$ ). Dissociated chromaffin cells from hypophysectomized rats are essentially indistinguish-
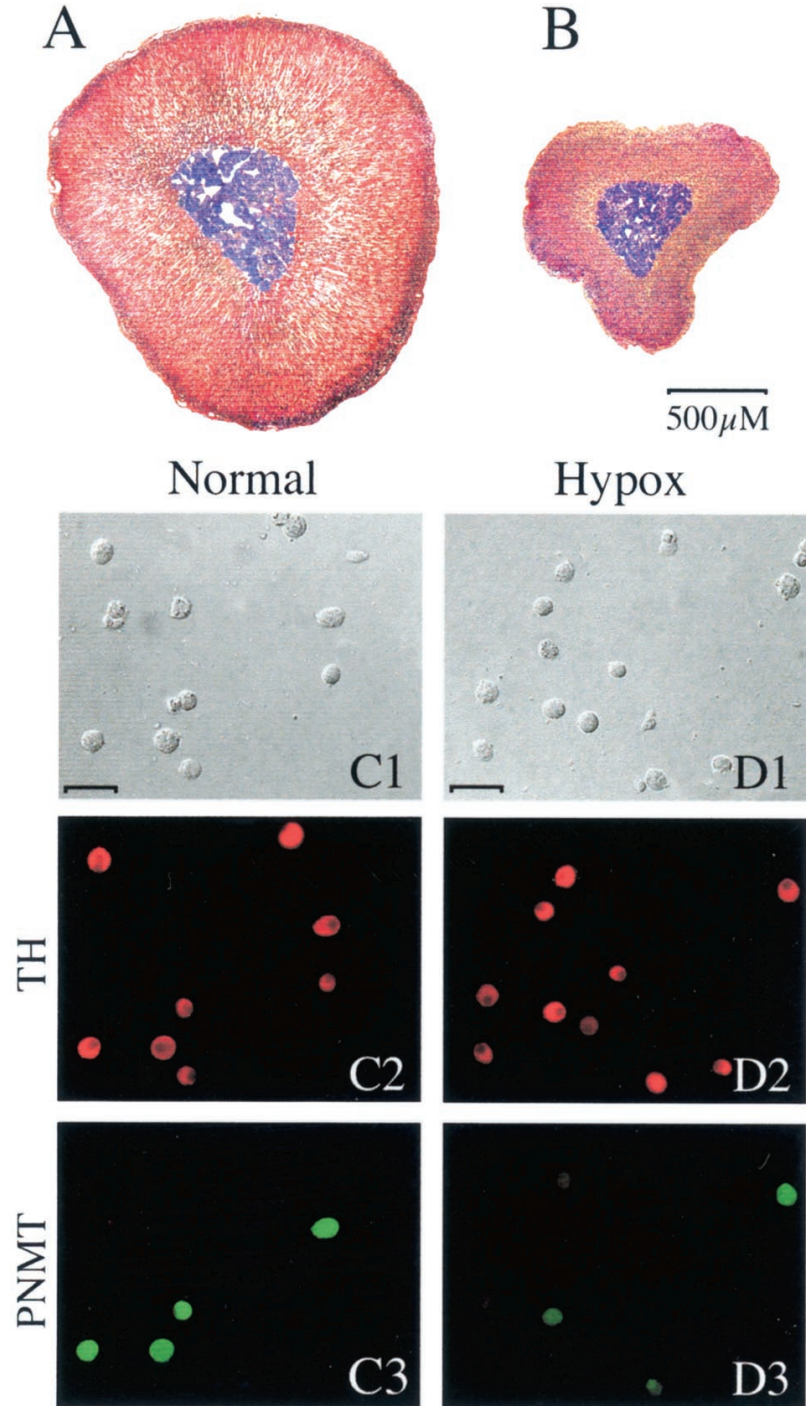

Figure 1. Effects of hypophysectomy on rat adrenal glands. $A, B$, Cross sections of normal $(A)$ and hypox $(B)$ adrenals stained with hematoxylin and eosin illustrate the anatomical differences. Note the smaller overall size of the hypox gland and the convex surface and reduced relative area of cortex, particularly the inner zona reticularis, relative to medulla. $C, D$, Dissociated medullary cells viewed under bright field $(C 1, D 1)$ and immunofluorescence after staining for the catecholamine-synthesizing enzyme TH $(C 2, D 2)$ appear essentially unaffected by hypophysectomy. In contrast, hypox cells exhibited a reduced immunoreactivity to the epinephrine-synthesizing enzyme PNMT (C3, D3), with substantially fewer, although not a complete loss of, strongly reactive cells. Scale bar: $C 1, D 1,50 \mu \mathrm{m}$. 

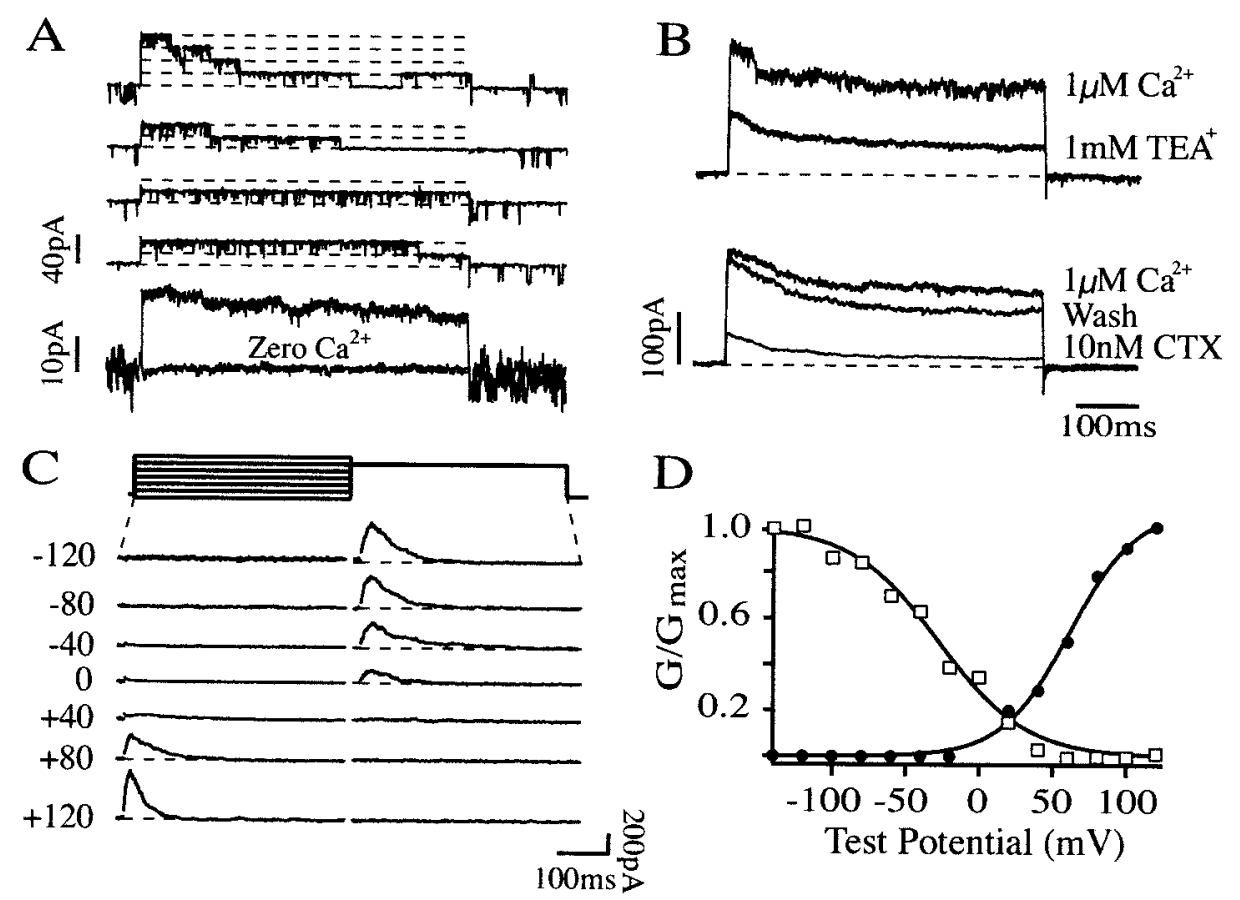

Figure 2. Hypophysectomized rat chromaffin cells express inactivating and non-inactivating large-conductance voltage- and calcium-dependent $\mathrm{K}^{+}$ currents. BK channel activation is tightly controlled by cytoplasmic $\left[\mathrm{Ca}^{2+}\right]$. A, Top four traces, Single traces recorded from an inside-out patch show the rapid activation of individual channels activated during consecutive steps to $+80 \mathrm{mV}$ in the presence of $1 \mu \mathrm{M}\left[\mathrm{Ca}^{2+}\right]_{\mathrm{i}}\left(V_{\mathrm{hold}}=-100 \mathrm{mV}\right)$. At least four to five large-conductance channels are visible above the baseline. Bottom trace, An ensemble average of 16 such steps reveals a mixture of both non-inactivating and slowly inactivating BK current components. Replacement of the $1 \mu \mathrm{M}\left[\mathrm{Ca}^{2+}\right]_{\mathrm{i}}$ with zero-calcium saline abolishes nearly all $\mathrm{K}^{+}$ current (washout not shown). $B$, BK channel characterization was further assessed by perfusion of pharmacological blockers onto channels in outside-out patches. Ensemble-averaged currents were suppressed by 60 and $90 \%$ after treatment with 1 mm TEA chloride (top) or $10 \mathrm{~nm}$ CTX (bottom), respectively. $C$, In an inside-out patch, ensemble-averaged traces produced by repeated steps to $+80 \mathrm{mV}$ from a series of increasingly positive conditioning potentials activated a rapid and completely inactivating voltage-dependent potassium current (conditioning voltages shown to the left of each trace). D, Peak conductance measurements of the currents in $C$ were plotted as a function of the conditioning potential and fit to Boltzmann equations to illustrate the voltage dependence of BK channel activation $(\bullet)$ and inactivation $(\square)$.

able from those from unoperated rats when viewed under a light microscope (Fig. 1C1,D1). Fluorescent immunoreactivity using antibodies directed against the catecholamine-synthetic enzyme TH also appeared very similar, confirming their identification as chromaffin cells (Fig. 1C2,D2). Although some hypox cells were strongly positive for PNMT, the intensity of staining for most cells was substantially lower than that for cells from normal animals (Fig. 1C3,D3). This observation is consistent with what is known about glucocorticoid regulation of PNMT expression in chromaffin cells (Ross et al., 1990; Betito et al., 1992; Evinger et al., 1992). The total yield of cells was consistently lower from hypox animals, approximately commensurate with, and presumed to result from, the cessation of somatic growth accompanying the loss of growth hormone-producing pituitary cells.

Inside-out patches pulled from hypophysectomized rat chromaffin cells were qualitatively similar to those from unoperated animals. BK channels are characterized by their codependence on voltage and cytoplasmic $\left[\mathrm{Ca}^{2+}\right]$ as well as their large singlechannel conductance. Activation of currents elicited by a step to $+80 \mathrm{mV}$ from negative holding potentials $\left(\mathrm{V}_{\mathrm{h}}=-100 \mathrm{mV}\right)$ revealed channels with activation and inactivation kinetics requiring significant membrane depolarization in constant $1 \mu \mathrm{M}$ $\left[\mathrm{Ca}^{2+}\right]_{\mathrm{i}}$. As discussed below, both hypox and normal rat patches typically expressed predominantly inactivating $\left(\mathrm{BK}_{\mathrm{i}}\right)$ current, although sustained $\left(\mathrm{BK}_{\mathrm{s}}\right)$ and mixed $\left(\mathrm{BK}_{\mathrm{i}}\right.$ and $\left.\mathrm{BK}_{\mathrm{s}}\right)$ currents were found in a smaller number of patches. A series of traces (Fig. $2 A$, top four traces) recorded from a small hypox patch exhibiting a
mixed-BK phenotype reveals at least three to four $\mathrm{BK}_{\mathrm{i}}$ channels and at least one sustained or very slowly inactivating $\mathrm{BK}_{\mathrm{s}}$ channel. In agreement with previous reports for normal rat chromaffin cells (Solaro et al., 1995; Lovell et al. 2000), single-channel conductances for both channel types were calculated to be $\sim 270$ $\mathrm{pS}$ (in symmetrical $\mathrm{K}^{+}$). An ensemble average of 16 traces (Fig. $2 A$, bottom trace) illustrates the dependence of the channels on intracellular $\left[\mathrm{Ca}^{2+}\right]$. The $\sim 25 \mathrm{pA}$ current present in $1 \mu \mathrm{M} \mathrm{Ca}^{2+}$ was almost entirely absent in zero $\mathrm{Ca}^{2+}$ saline. As discussed below, few if any additional voltage-dependent channels were activated by this step in the absence of $\mathrm{Ca}^{2+}$. The current was quickly restored after return to normal saline (washout not shown).

Both inactivating and non-inactivating BK currents in normal and hypox cells exhibited BK-typical pharmacological block by relatively low concentrations of $\mathrm{TEA}^{+}$and CTX, as illustrated in Figure $2 B$. Perfusion of $\mathrm{TEA}^{+}(1 \mathrm{~mm})$ onto outside-out patches produced a reversible reduction by at least $50 \%$, and 10 nм CTX reduced the current by $\sim 90 \%$. Currents other than BK in patches were small. Exposure of the same inside-out patch to either potassium chloride- or potassium methanesulfonate-based salines yielded virtually identical results, suggesting that few if any chloride channels or chloride-sensitive $\mathrm{K}^{+}$channels are expressed in chromaffin cells. We occasionally recorded a calcium-dependent leak current with little single-channel noise and no voltage dependence, but this tended to diminish within a few minutes and was eliminated by leak subtraction protocols. There was no sig- 


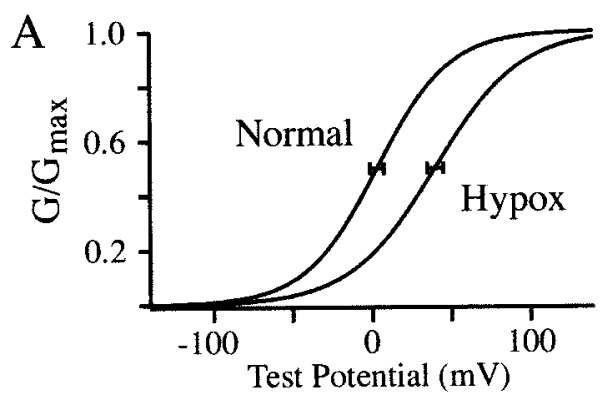

C

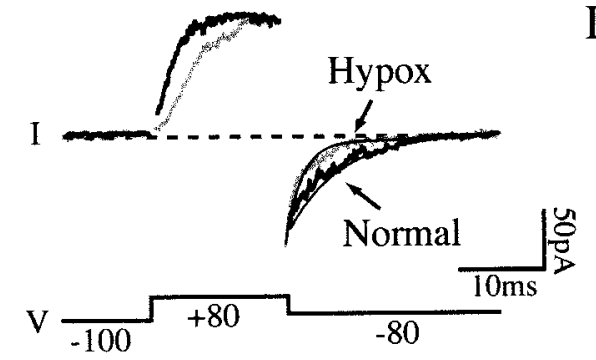

B

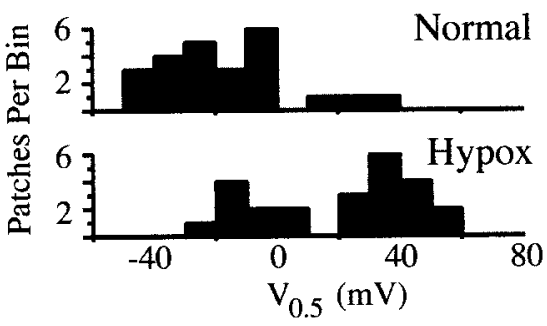

D

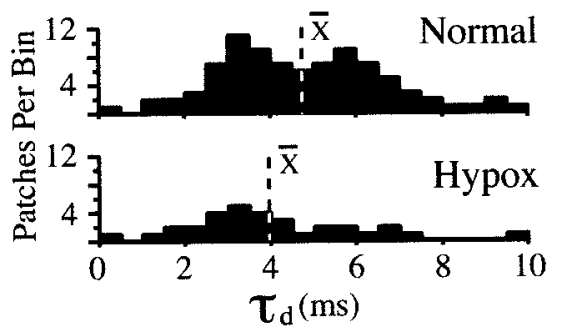

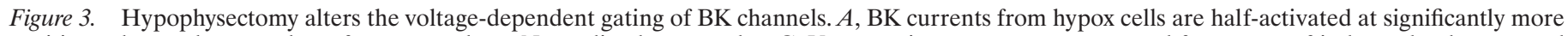

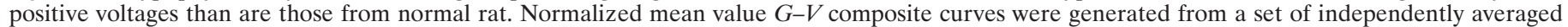

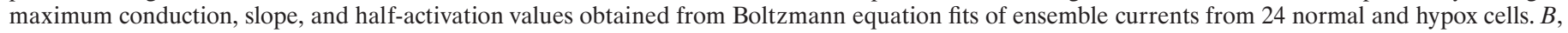

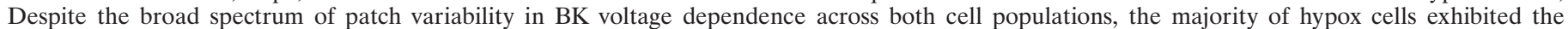

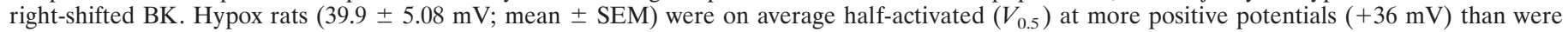

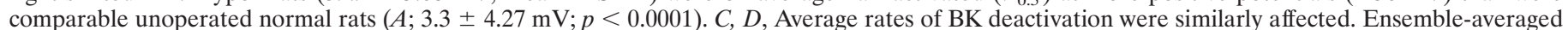

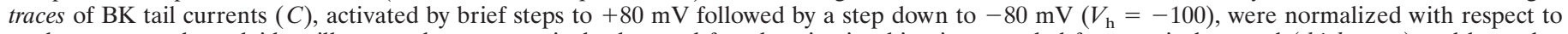

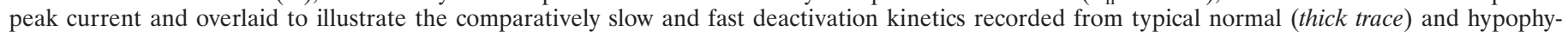

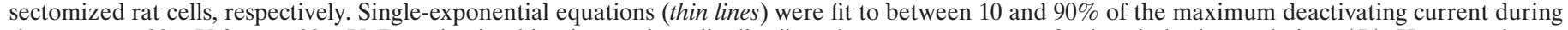

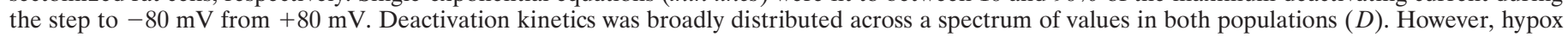

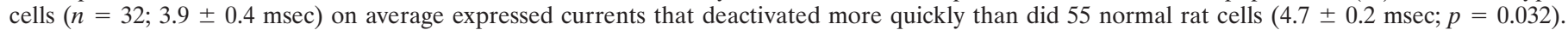

nificant contribution to the current traces by voltage-gated channels that were calcium independent in either normal or hypox cells. Occasionally a voltage- and calcium-independent current with single-channel conductance approaching that of BK channels was recorded. The occurrence of such channels did not differ detectably between normal and hypox cells, but patches in which these channels interfered with measurement of the voltagedependent component were excluded from the data analysis.

Peak amplitudes measured from macroscopic-like ensemble traces were used to determine the voltage dependence of activation and inactivation. In Figure $2 C$, sample traces from a typical patch expressing predominantly $\mathrm{BK}_{\mathrm{i}}$ current are shown. Depending on the number of channels in the patch and the time available before patch breakdown, 5-15 repeat traces were averaged for conductance $(G)$ values (Fig. $2 D)$.

\section{Hypophysectomy alters the voltage-dependent gating of chromaffin BK currents}

Comparisons of STREX and ZERO splice variants of Slo in Xenopus oocyte expression studies demonstrated that the inclusion of STREX shifts the voltage dependence of gating in the negative direction, or enhances the apparent calcium sensitivity. The observed reduction in STREX associated with hypophysectomy (Xie and McCobb, 1998) would thus predict a positive shift in the voltage dependence of activation of native BK channels with hypophysectomy. To test this we stepped patches from normal and hypox chromaffin cells to increasingly positive test potentials in $20 \mathrm{mV}$ increments. Cells were initially held at a holding potential of $-140 \mathrm{mV}$, a value sufficiently negative to deinactivate, and thus uncover, virtually all available channels. The voltage dependence of half-activation $\left(V_{0.5}\right)$ was then deter- mined by plotting peak conductance values as a function of test potential and fitting the points with a standard Boltzmann equation. On average, patches from hypox cells required more positive test potentials for activation than did patches from normal cells. Thus mean $V_{0.5}$ values ( \pm SEM) for hypox patches were $36 \mathrm{mV}$ more positive than were those for normal patches (Fig. 3A) (39.9 $\pm 5.08 \mathrm{mV}$ for 24 hypox patches compared with $3.3 \pm 4.27$ $\mathrm{mV}$ for 24 normal patches; $p<0.0001)$. The steepness of the voltage dependence was not significantly different between groups $(31.3 \pm 2.7$ and $24.6 \pm 6.5 \mathrm{mV} / \mathrm{e}$-fold change in conductance for hypox and normal patches, respectively). From the frequency distribution in Figure $3 B$, it is evident that both populations exhibited a broad range of $V_{0.5}$ values. The wide variability of voltage-dependent gating observed can be partially explained by heterogeneous mixing of BK channel types. Thus in individual cells, BK channels may be composed of varying proportions of STREX and ZERO-like subunits (as well as $\beta$ subunits) as determined by a binomial expansion from the percentages of starting subunits. Lovell et al. (2000) and Ding et al. (1998) have argued that a similar model can accurately predict the broad range of $\mathrm{BK}$ channel inactivation rates that has been observed in both the rat and bovine chromaffin cell population (see description below).

Previous studies showed that in conjunction with the shift in the voltage of half-activation, inclusion of STREX in oocyteexpressed Slo transcripts increases and decreases the rates of activation and deactivation gating, respectively (Saito et al., 1997; Xie and McCobb, 1998). Our comparison of native BK gating kinetics in normal and hypox chromaffin cell patches gives results consistent with a decrease in the relative abundance of STREX 
splice variants associated with hypophysectomy. In Figure $3 C$, averaged ensemble traces from hypox and normal rat inside-out patches were overlaid to illustrate the typical effect of hypophysectomy on the rates of channel activation and deactivation. Despite heterogeneity across both populations (Fig. 3D), hypophysectomy decreased the average time constant for deactivation from $4.7 \pm 0.2 \mathrm{msec}($ mean $\pm \mathrm{SE})$ to $3.9 \pm 0.4 \mathrm{msec}(n=55$ normal and 32 hypox patches, respectively; $p=0.032$ ). Time constants for activation averaged $2.0 \pm 0.3$ and $3.9 \pm 0.5 \mathrm{msec}$ for 55 normal and 32 hypox patches, respectively $(p=0.0005)$. The distributions of deactivation values indicate a greater proportion of slowly deactivating patches in normal cells (Fig. 3D). Apparent bimodalities in the distributions of $V_{0.5}$ values and deactivation kinetics (Fig. 3B,D) raise the possibility that hypophysectomy might functionally alter a subpopulation of cells. However, sampling limitations and the difficult nature of these measurements prevent a firm conclusion at this time. Taken together, the results described above are consistent with the idea that a decrease in the relative abundance of STREX-containing channel subunits after surgical ablation of the pituitary alters the gating properties of native BK channels.

\section{BK inactivation is unaffected by hypophysectomy}

The rate and extent of inactivation have been shown to vary dramatically across chromaffin cell populations of rat and bovine, as well as between the species (Solaro et al., 1995; Lingle et al., 1996; Lovell et al., 2000). In oocytes coinjected with Slo cRNA, at least two distinct but related accessory subunits can confer rapid inactivation that is similar to that in native chromaffin cells (Wallner et al., 1999; Xia et al., 1999, 2000; Uebele et al., 2000). These and other related $\beta$ subunits that do not confer inactivation can markedly shift the voltage dependence of activation gating as well, although the latter effect varies between them. To address whether inactivation properties are subject to regulation by pituitary hormones, ensemble currents from numerous multichannel patches were obtained. Inactivation properties were not appreciably different between hypox and normal cells.

Patches from either normal or hypox rats were categorized as $\mathrm{BK}_{\mathrm{i}}$ if at least $90 \%$ of the peak current in a patch inactivated within $350 \mathrm{msec}$ and $\mathrm{BK}_{\mathrm{s}}$ if at least $90 \%$ of the current was sustained through $350 \mathrm{msec}$ (see Materials and Methods for details). Similar to what has been described previously for normal rat cells (Neely and Lingle, 1992a,b; Solaro et al., 1995; Lovell et al. 2000), the majority $(67.1 \%)$ of hypox patches were found to express the rapid and completely inactivating variant of BK (Fig. $4 A$, top left trace), whereas smaller proportions exhibited the more slowly inactivating mixed current $(24.4 \%$; $n=20$; Fig. $4 A$, top right, bottom left traces) or completely non-inactivating $\mathrm{BK}_{\mathrm{s}}$ current $(8.5 \% ; n=7$; Fig. $4 \mathrm{~A}$, bottom right trace). The results are
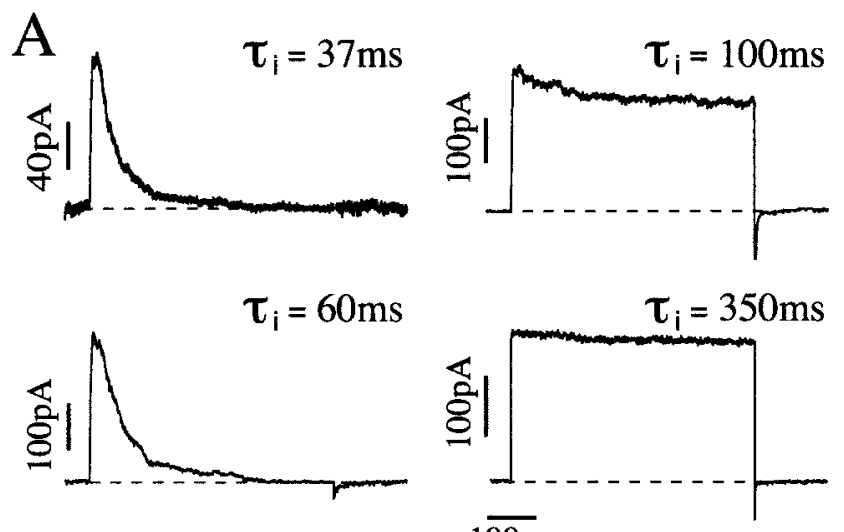

B

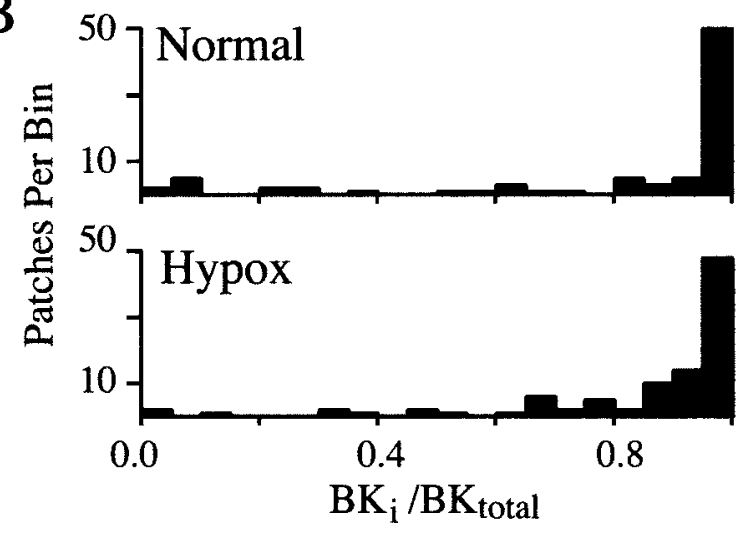

Figure 4. BK current inactivation appears unaffected by hypophysectomy. $A$, Ensemble-averaged currents activated by steps to $+80 \mathrm{mV}$ in the presence of 4 or $1 \mu \mathrm{M}\left[\mathrm{Ca}^{2+}\right]$ illustrate the wide range of channel inactivation kinetics found across the hypox cell population. The measured rate constant of inactivation is shown at the top right of each trace. $B$, Frequency distributions showing the proportion of total current inactivated during a $350 \mathrm{msec}$ step $\left(B K_{i} / B K_{\text {total }}\right)$ suggest that the hypox cells exhibit inactivation properties $(n=82)$ that are very similar to those featured in normal cells $(n=97)$.

detailed in Table 1. No significant difference was found in the fraction of current inactivated during a $350 \mathrm{msec}$ voltage step $\left(\mathrm{BK}_{\mathrm{i}} / \mathrm{BK}_{\text {total }}\right)$ in $1 \mu \mathrm{M} \mathrm{Ca}{ }^{2+}$ measured in 58 hypox $(0.81 \pm 0.04$; mean $\pm \mathrm{SE})$ and 73 normal $(0.86 \pm 0.03 ; p=0.74)$ patches. Histograms plotting the distribution of $\mathrm{BK}_{\mathrm{i}} / \mathrm{BK}_{\text {total }}$ values for the normal and hypox populations appear nearly indistinguishable (Fig. 4B). Time constants of inactivation measured in a subset of 47 hypox and 67 normal cells, excluding those expressing extremely slow or non-inactivating currents, measured $49.1 \pm 3.0 \mathrm{msec}$ as compared with $48.0 \pm 2.2 \mathrm{msec}(p=0.81)$, respectively. These

Table 1. Breakdown of the numbers of inside-out patches expressing only $\mathrm{BK}_{\mathrm{i}}, \mathrm{BK}_{\mathrm{s}}$, or both $\mathrm{BK}_{\mathrm{i}}$ and $\mathrm{BK}_{\mathrm{s}}$ in chromaffin cells from normal and posthypophysectomy adrenal glands

\begin{tabular}{|c|c|c|c|c|c|}
\hline & {$\left[\mathrm{Ca}^{2+}\right]$} & $\mathrm{BK}_{\mathrm{i}}$ & $\mathrm{BK}_{\mathrm{s}}$ & $\mathrm{BK}_{\mathrm{i}}$ and $\mathrm{BK}_{\mathrm{s}}$ & Totals \\
\hline \multirow[t]{3}{*}{ Hypox } & $1 \mu \mathrm{M}$ & $41(71.9)^{a}$ & $5(8.8)$ & $11(19.3)$ & 57 \\
\hline & $4 \mu \mathrm{M}$ & $14(56.0)$ & $2(8.0)$ & $9(36.0)$ & 25 \\
\hline & Totals & $55(67.1)$ & $7(8.5)$ & $20(24.4)$ & 82 \\
\hline \multirow[t]{3}{*}{ Normal } & $1 \mu \mathrm{M}$ & $48(65.8)$ & $2(2.7)$ & $23(31.5)$ & 73 \\
\hline & $4 \mu \mathrm{M}$ & $14(58.3)$ & $0(0.0)$ & $10(41.7)$ & 24 \\
\hline & Totals & $62(63.9)$ & $2(2.1)$ & $33(34.0)$ & 97 \\
\hline
\end{tabular}

${ }^{a}$ Numbers in parentheses indicate the percentages of patches. 
A
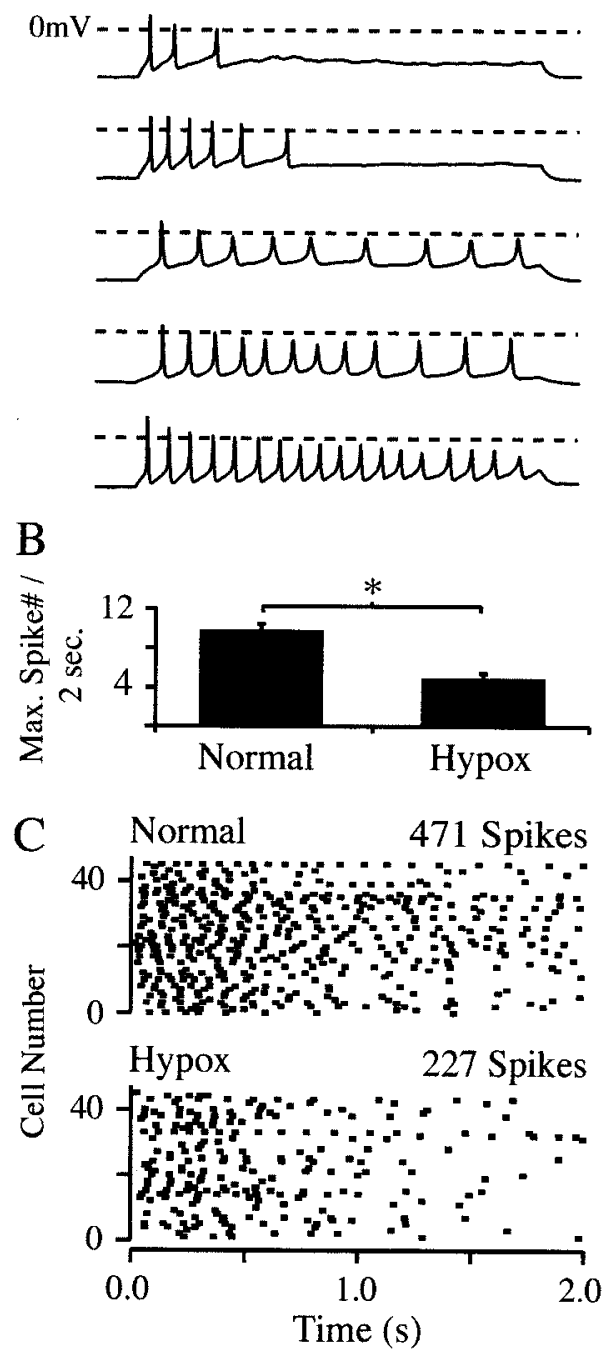

Hypox
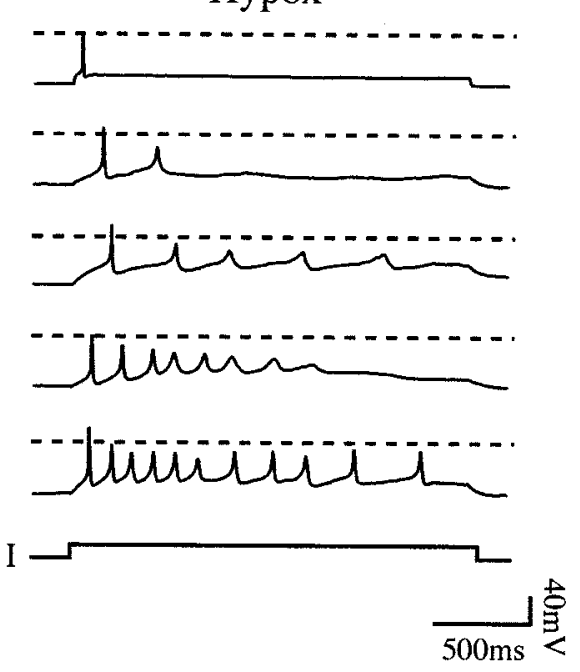

$\mathrm{D}$

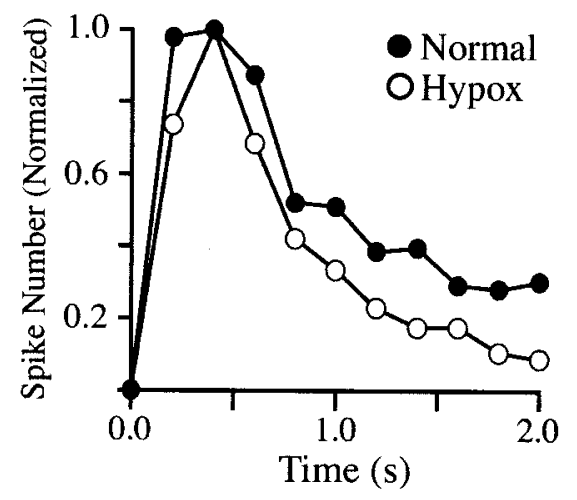

Figure 5. Chromaffin cell repetitive firing properties are altered by hypophysectomy. $A$, Series of spike trains recorded from typical hypox and normal rat cells are plotted to illustrate the broad range of spiking abilities across both cell populations. In some cells the 2 sec depolarizing pulse was only capable of maximally eliciting a single spike $(A$; top right trace), whereas in others 18 or more could be generated $(A ;$ bottom left trace). $B$, On average, hypox cells were found to fire significantly fewer spikes per $2 \mathrm{sec}$ pulse $(4.88 \pm 0.46$; mean $\pm \mathrm{SEM} ; n=48)$ than did comparable normal cells $(9.67 \pm$ $0.69 ; n=56 ; p<0.0001)$. The asterisk indicates that mean values were significantly different according to a standard Student's $t$ test $\left({ }^{*} p<0.05\right)$. $C$, To characterize changes in the temporal dynamics of repetitive firing, the precise timing of individual spikes from 48 hypox and normal cell traces that exhibited maximum firing were plotted against time on a raster diagram. The hypox cell population fired fewer total APs (227 vs 471 APs) than did normal cells. $D$, Poststimulus time histograms from the cells in $C$, normalized with respect to the total number of spikes, show that hypox cells exhibit a more rapid time-dependent decay in firing frequency than do normal cells.

results suggest that the expression of $\beta$ subunits that confer inactivation is not under dynamic regulatory control by the pituitary.

\section{The excitable properties of chromaffin cells are altered by hypophysectomy}

The BK functional heterogeneity that is apparent in rat and bovine chromaffin cells has been postulated to underlie differences in their firing properties, particularly with respect to rapid repetitive firing (Solaro et al., 1995; Lingle et al., 1996; Xie and McCobb, 1998; Lovell et al., 2000). Because an HPA-related change in chromaffin cell excitability could have profound consequences on the neurosecretory output of catecholamines, we have addressed whether hypophysectomy measurably alters excitability per se by the use of perforated-patch methods with current-clamp electronics. From both normal and hypox cells, characteristically large action potentials, overshooting $0 \mathrm{mV}$ and with similar wave- forms, could be elicited (Fig. 5A). Trains of action potentials could be elicited by 2 -sec-duration, suprathreshold current injections. A broad range of spiking responses was evident across both cell populations, ranging from cells responding with no more than a single spike (Fig. 5A, top right trace) to those responding with a varying number of spikes, peaking at up to 18 , during the $2 \mathrm{sec}$ injection (Fig. 5A, bottom left trace). Considerable variation in spike amplitude and duration was encountered, as discussed below. Normal and hypox cells did not differ measurably with respect to input resistance or mean initial resting potential.

Chromaffin cells from hypox animals showed a markedly lower propensity for repetitive firing. The number of spikes elicited by a progressive series of long, current injection steps has been used as an indicator of repetitive firing properties of chromaffin cells (Solaro et al., 1995). Chromaffin action potentials can be carried 
by $\mathrm{Na}^{+}, \mathrm{Ca}^{2+}$, or both ionic currents. Progressive inactivation of $\mathrm{Na}^{+}$channels during a train of action potentials typically produces a graded decrease in spike amplitude and an increase in spike duration and $\mathrm{Ca}^{2+}$ dependence. Previous studies suggest that catecholamine exocytosis can be triggered by the rapid rise in intracellular $\left[\mathrm{Ca}^{2+}\right]$ associated with the activation of a variety of voltage-dependent $\mathrm{Ca}^{2+}$ channels (Artalejo et al., 1994; López et al., 1994). Therefore, we counted as a spike any quick, transient voltage inflection that exceeded the baseline and was indicative of the regenerative activation of $\mathrm{Na}^{+}$or $\mathrm{Ca}^{2+}$ channels. To minimize variation from preexisting $\mathrm{Na}^{+}$or $\mathrm{Ca}^{2+}$ channel inactivation, the membrane potential between steps was held between -70 and $-75 \mathrm{mV}$, by manually adjusting a small holding current, if needed. The beginning amplitude and serial increment of the steps were adjusted by trial and error to fit the input resistance of the cell, raising the "baseline" voltage during the step at modest increments through the range over which spikes could be elicited. Under these conditions, hypox cells were consistently found to fire many fewer spikes than did normal cells. On average, the maximum number of spikes that could be elicited was $4.88 \pm 0.46$ (mean \pm SEM; $n=48$ ) for hypox cells compared with $9.67 \pm 0.69$ for normal cells (Fig. $5 B)(n=56 ; p<0.0001$, Student's unpaired $t$ test for mean differences). The raster plots and frequency distributions in Figure 5,C and $D$, illustrate the differences between treatment groups. Differences in the peak frequency of action potential generation in the earlier part of the steps and in the tendency to continue firing over the step duration both contribute to the mean differences in spike numbers (Fig. 5D).

Features of the action potential waveform also differed between normal and hypox cells (Fig. 6). Among normal and hypox cells capable of firing at least one spike, the action potential peak-totrough amplitude was slightly greater for normal than for hypox cells (Fig. $6 B)(p=0.005,0.078$, and 0.010 for first, second, and third spikes, respectively). Moreover, the AHP amplitude (the difference between the baseline voltage and the voltage at the bottom of the trough) was smaller for hypox than for normal cells (Fig. $6 C$ ), and half-amplitude duration was greater for hypox than for normal cells (Fig. 6D) $(p=0.06,0.015$, and 0.003 for first, second, and third spikes, respectively). The divergence between normal and hypox AP waveforms continued to progress beyond the first three spikes, as can be observed qualitatively in Figure $5 \mathrm{~A}$.

The observed differences in action potential waveform could be primarily or fully attributed to the changes in BK functional properties described above. Although changes in $\mathrm{Na}^{+}$or $\mathrm{Ca}^{2+}$ current density that are associated with hypophysectomy, if they occur, could contribute to waveform changes, reduced activation of BK channels would be expected to both slow repolarization and diminish the AHP. This would increase the number of channels entering an inactivated state and reduce the number recovering from inactivation, thus decreasing the number of $\mathrm{Na}^{+}$ channels available to drive subsequent spikes. In turn, the shorter resulting spikes would be less effective in activating BK channels, worsening the progressive spike broadening and further diminishing the AHP. Functional BK channels could thus be the critical factor in minimizing the progressive accumulation of $\mathrm{Na}^{+}$and $\mathrm{Ca}^{2+}$ channels in an inactivated state. A sharp decrease in BK channel expression with hypophysectomy might also affect AP waveforms and repetitive firing, an argument that would be functionally equivalent to a positive shift in the gating of individual channels. However, this is difficult to measure in whole-cell mode, independent of changes in calcium current, because of the complexity introduced by the interaction between changes in the BK
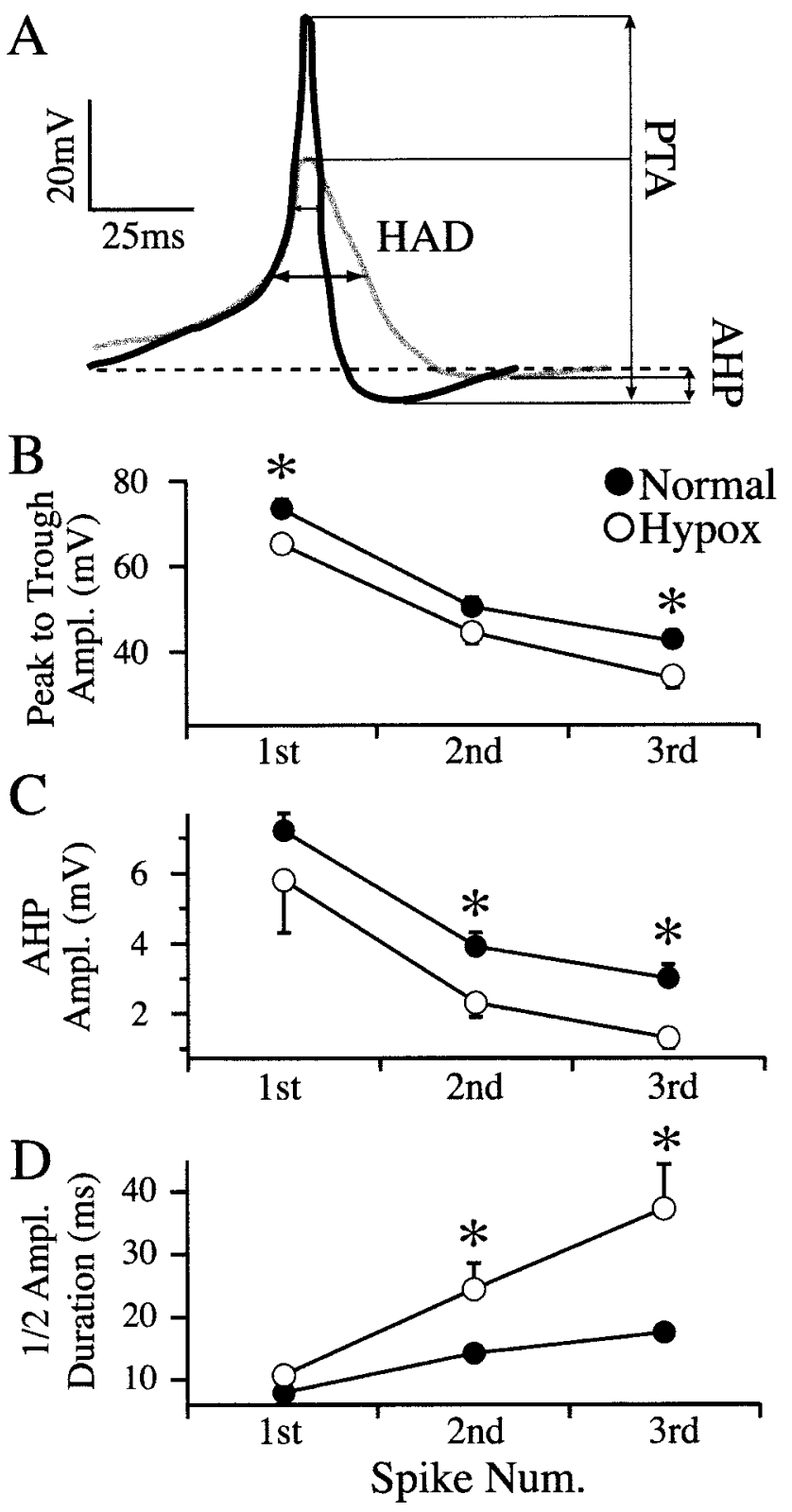

Figure 6. Hypophysectomy decreases repetitive firing, altering features of the action potential waveform. $A$, The third APs from a normal and a hypox trace were selected and overlaid to illustrate the effect of hypophysectomy on spike waveform. From such traces, the peak-to-trough amplitude (PTA), the magnitude of the AHP, and the half-amplitude spike duration (HAD) were measured for a subset of cells capable of firing at least a single spike. A more detailed description of the methods used to quantify AP waveform features can be found in Materials and Methods. $B$, Normal cells were found to have a greater PTA than do hypox cells ( $p=0.005,0.078$, and 0.010 for the first, second, and third spikes, respectively). $C$, Similarly, the absolute magnitude of the AHP was found to be larger for normal than for hypox cells $(p=0.332,0.014$, and 0.003 for the first, second, and third spikes, respectively). $D$, HADs for the first three action potentials were greater for hypox than for normal cells $(p=0.06$, 0.015 , and 0.003 for the first, second, and third spikes, respectively). Asterisks indicate that mean values were significantly different according to a standard Student's $t$ test $\left({ }^{*} p<0.05\right)$. Ampl., Amplitude; Num., number.

primary voltage dependence and the secondary voltage dependence of the BK channel, which derives both from the voltagedependent gating of calcium channels and the U-shaped calcium $I-V$ curve. 

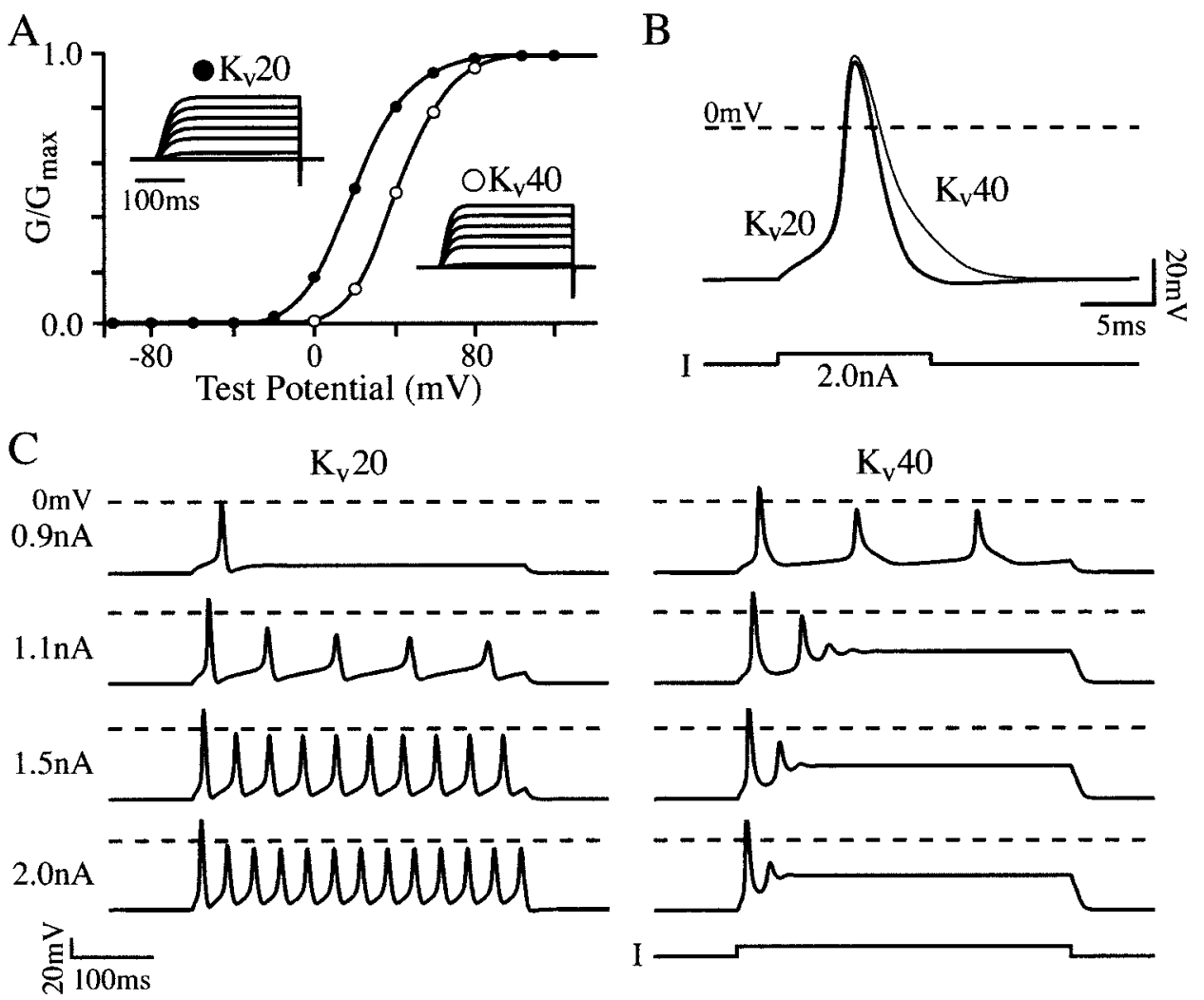

Figure 7. A conductance-based model composed of a voltage-gated sodium current, a leak current, and a potassium current can exhibit dramatic differences in repetitive firing ability. A detailed description of the model can be found in Materials and Methods. $A$, A conductance-voltage plot ( $G-V$ ) shows the steady-state activation for the two voltage-dependent potassium currents used in the model $\left(I_{\mathrm{Kv}} 20, I_{\mathrm{Kv}} 40 ; 20\right.$ and 40 represent measured $V_{0.5}$ values for each channel). The $G-V$ plots were constructed by plotting the peak values of currents ( $A$, inset graphs) activated in a symmetrical potassium gradient by a series of increasing test potentials. $B$, An expanded view of the first APs elicited from the $I_{\mathrm{Kv}} 20$ (thick line) and $I_{\mathrm{Kv}} 40$ (thin line) model cells by a short $2 \mathrm{nA}$ current pulse is shown. Shifting the voltage dependence of activation in the negative direction effectively decreased the half-amplitude spike duration while increasing the magnitude of the AHP. $C$, Over a broad range of depolarized membrane potentials, the cell expressing the $I_{\mathrm{Kv}} 20$ potassium current (left) was better able to sustain repetitive firing than was the cell expressing only the $I_{\mathrm{Kv}} 40$ channels (right). Current injection values are shown to the left of each pair of plots.

The results presented here suggest that BK channels can drive rapid AP repolarization and enhance the duration and amplitude of AHPs, properties speculated to be important for facilitating repetitive firing. Recent modeling studies of turtle cochlear hair cell electrical tuning (Wu and Fettiplace, 1996) and rat hippocampal pyramidal cell spike broadening (Shao et al., 1999) suggest that even subtle shifts in the voltage dependence and/or kinetics of potassium channel gating will significantly alter features of cellular excitability. To investigate these issues we constructed a mathematical simulation of cellular excitability using the computational modeling package Nodus (De Schutter, 1989). Two noninactivating voltage-dependent potassium currents $\left(I_{\mathrm{Kv}} 20\right.$ and $I_{\mathrm{Kv}} 40$; numbers indicate $V_{0.5}$ values for the respective currents) were independently paired with a classical Hodgkin and Huxleytype fast-inactivating sodium current (Hodgkin and Huxley, 1952) (Fig. 7A) and a leak current in a model cell with dimensions and physical parameters similar to those measured in rat chromaffin cells. A detailed description of the modeling parameters can be found in Materials and Methods. In a symmetrical potassium gradient, brief steps to positive potentials from $-100 \mathrm{mV}$ activate voltage-dependent currents (see Fig. $7 A$, inset graphs). Conductance-voltage plots, constructed by plotting the peak current as a function of the test potential, illustrate the $\sim 20 \mathrm{mV}$ shift in the voltage dependence of half-activation between $I_{\mathrm{Kv}} 20$ and $I_{\mathrm{Kv}} 40$ (Fig. $7 A$ ). As predicted by the shift in voltage dependence, the rates of $I_{\mathrm{Kv}} 20$ channel activation and deactivation were also faster and slower than were those of $I_{\mathrm{Kv}} 40$, respectively. The effect of this voltage shift on repetitive firing properties is illustrated in Figure $7 C$. Over a broad range of $1 \mathrm{sec}$ depolarizing current pulses $(0-2 \mathrm{nA})$, the $I_{\mathrm{Kv}} 20$ cell responded with a greater range of sustained spiking (between 1 and $13 \mathrm{APs} / \mathrm{sec}$ ) than did the $I_{\mathrm{Kv}} 40$ cell (2-3 APs/sec; Fig. 7C). An overlay of the first APs from the $I_{\mathrm{Kv}} 20$ and $I_{\mathrm{Kv}} 40$ cells elicited by a brief $10 \mathrm{msec}(2 \mathrm{nA})$ depolarizing step suggests that both an increased AHP amplitude and fast AP repolarization, features promoted by the left-shift in the voltage dependence of gating, play a role in facilitating increased excitability (Fig. 7B). These results argue that even in the simplest scenario (i.e., a cell that contains only two distinct channel types), shifting the voltage dependence of potassium channel gating in the negative direction can greatly enhance repetitive firing ability. As such, the modeling results support the idea that a shift in BK channel properties resulting from hypophysectomy can at least in part explain the increased firing ability observed in the normal rat cells.

The idea that BK channels enhance repetitive firing ability in chromaffin cells is further supported by pharmacological experiments. The contributions of BK channels to AP waveform and repetitive firing were explored by applying $1 \mathrm{mM} \mathrm{TEA}^{+}$during current-clamp recording. This concentration typically blocks BK current by $>60 \%$ in outside-out patches (see Fig. $2 B$ ). TEA ${ }^{+}$ reversibly reduced the repetitive firing of all seven cells that 

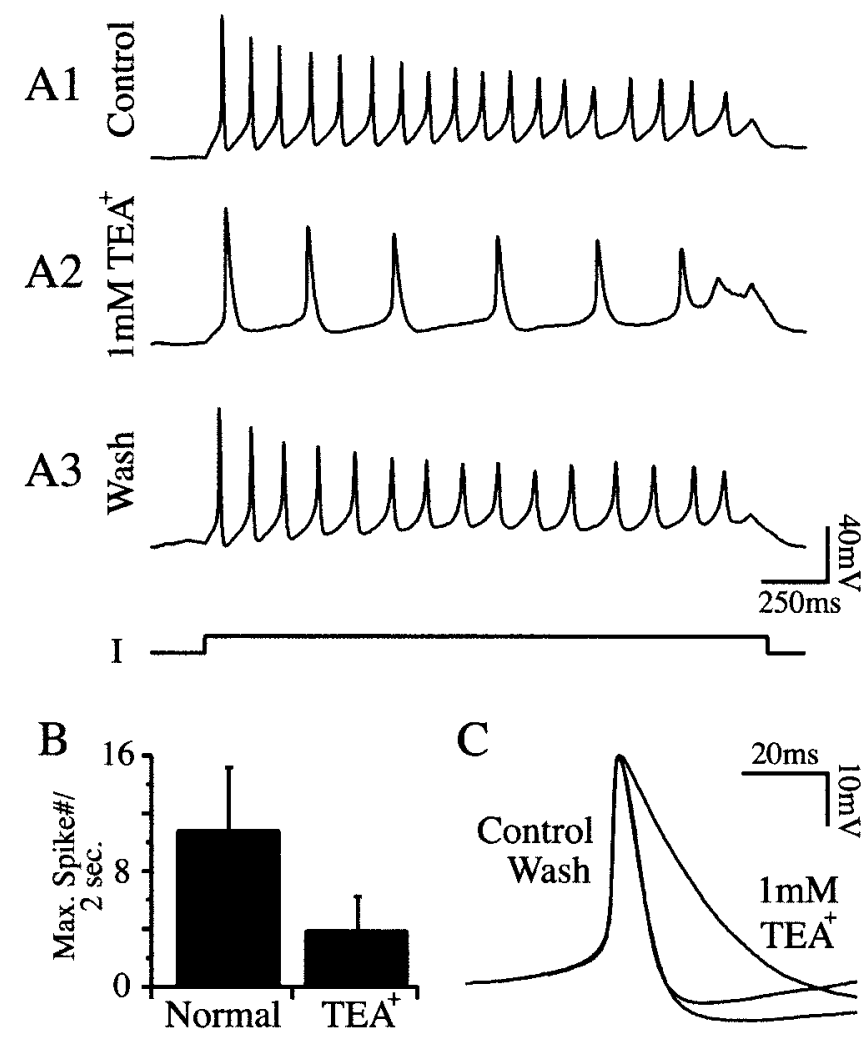

Figure 8. Blockade of channel function significantly reduces repetitive firing. A1, Typical normal chromaffin cells can be stimulated to fire $>15$ spikes during a $2 \mathrm{sec}$ depolarizing current pulse. $A 2$, Subsequent bath application of $1 \mathrm{mM} \mathrm{TEA}^{+}$, a potent blocker of $\mathrm{BK}$ channel activation, reversibly reduces the maximum rate of firing by $>70 \%$. A3, Replacement of the bath saline with the standard recording solution quickly restores normal firing ability. $B$, Treatment with TEA ${ }^{+}$significantly reduced the average rate of firing from $10.9 \pm 4.5$ spikes/2 sec (mean \pm SD) to $3.9 \pm$ 2.2 spikes $/ 2 \sec (n=7 ; p<0.0001)$. $C$, Specifically, $\mathrm{TEA}^{+}$-mediated BK blockade (second spike in $A 1-A 3$ expanded) results in reproducible spike broadening and a reduction in the magnitude of the AHP.

otherwise fired a train of spikes in response to current steps from an average of $10.9 \pm 4.5 \mathrm{spikes} / 2 \mathrm{sec}($ mean $\pm \mathrm{SD})$ to $3.9 \pm 2.2$ spikes/2 sec $(p<0.0001$; Fig. $8 A, B)$. TEA $^{+}$application also increased the average spike duration by at least twofold $(22.0 \pm$ 10.0 vs $8.3 \pm 1.6 \mathrm{msec}$; TEA vs control), while significantly decreasing the magnitude of the AHP for the first spike $(0.4 \pm 0.7$ vs $7.5 \pm 1.6 \mathrm{mV} ; p<0.0001$; Fig. $8 C$ ). In agreement with previous studies using the BK channel blocker charybdotoxin (Solaro et al., 1995), these experiments further support the suggested role for BK channels in defining action potential waveform and repetitive firing properties and strongly suggest that the differences between normal and hypox chromaffin cell excitability are likely to derive from the differences in the voltage-dependent gating of BK channels in these cells.

Sustained chromaffin cell repetitive firing (or high-frequency patterns of stimulation) has been shown to favor increased catecholamine release via a primarily calcium-dependent mechanism (Zhou and Misler, 1995; Elhamdani et al., 1998). Thus in normal rat cells, repetitive spiking, characterized by long trains of relatively large-amplitude, short-duration APs, would be expected to facilitate calcium entry and epinephrine release by repeated activation of voltage-dependent calcium currents. By driving rapid AP repolarization and increasing spike AHP duration, BK channels would be predicted to facilitate calcium influx through open channels when the driving force is maximal. Alternatively, hypox rat APs, characteristically smaller and of longer duration, might provide for an elongated calcium-entry window, thus facilitating release. We therefore directly measured the effect of the AP waveform on the dynamics of calcium entry.

In whole-cell recording mode, a series of positively increasing voltage steps $\left(\mathrm{V}_{\mathrm{h}}=-70 \mathrm{mV}\right)$ activate large inward voltagedependent calcium currents (Fig. $9 A$ ) in normal and hypox rat cell populations $(n=5)$. No significant differences between the mean voltage of peak current activation or the kinetics of calcium channel activation were observed (Fig. 9B). To assess the importance of the action potential waveform in driving the influx of calcium, a set of APWs broadly representing the spectrum of APs recorded from normal and hypox cells was presented to either normal or hypox cells using the whole-cell patch-clamp recording configuration and solutions designed to isolate calcium currents. A short-HAD, large-PTA normal rat third AP (nAPW) and a long-HAD, short-PTA hypox third spike (hAPW) were presented to normal and hypox rat cells. Both cell types $(n=5)$ responded to the presentation of APWs with characteristic calcium spikes (Fig. 9C) that could be reversibly blocked by the addition of $100 \mu \mathrm{M}$ cadmium $\left(\mathrm{Cd}^{2+}\right)$ to the bath saline (result not shown). A measure of the ability of each APW to trigger calcium entry was established for the normal and hypox rat cells by dividing the integrated area under the hypox APW-triggered calcium spike (hCS) into that of the normal spike (nCS). The magnitude of the calcium currents elicited by presentation of the same APW to hypox and normal rat cells did not differ appreciably. On average, the ratio of calcium spike areas (nCS/hCS) was nearly identical for the normal and hypox cells $(0.98 \pm 0.06$ vs $0.91 \pm 0.16$; mean \pm SEM; Fig. 9D), suggesting that despite dramatic differences in the shapes of the APWs accumulated calcium entry would be similar.

As described, sustained spiking in chromaffin cells favors catecholamine exocytosis via a primarily calcium-dependent mechanism. To examine the effect of repetitive firing on calcium entry we presented both normal and hypox cells with spike train waveforms recorded previously from normal and hypox rat cells. Calcium spikes elicited by trains of APWs closely followed the rate of spike presentation, although apparent calcium channel inactivation appears to result in reduced calcium spike amplitude during successive APWs. Plateau depolarization, a feature of some cells that fail to fire repetitively (see Fig. $5 A$ ), elicited only minor influxes of calcium that are unlikely to contribute significantly to transmitter release (Fig. 9E). Together, these experiments suggest that catecholamine release is likely to be increased more effectively by increasing repetitive firing properties than by broadening the APW.

\section{DISCUSSION}

The primary finding of this paper is that surgical ablation of the pituitary changes the properties of adrenal chromaffin BK channels as characterized in excised patches and also changes features of cellular excitability measured with the perforated-patch technique. More specifically, BK currents in patches from hypox chromaffin cells typically reach half-maximal activation at more positive voltages, activate more slowly, and deactivate more rapidly than do channels in patches from normal animals. Features of cellular excitability that were found to differ in perforated-patch recordings included changes in action potential waveform and the maximum numbers of spikes that could be elicited during prolonged depolarizing current injection. Enhanced repetitive firing 
A

$\mathrm{C}$
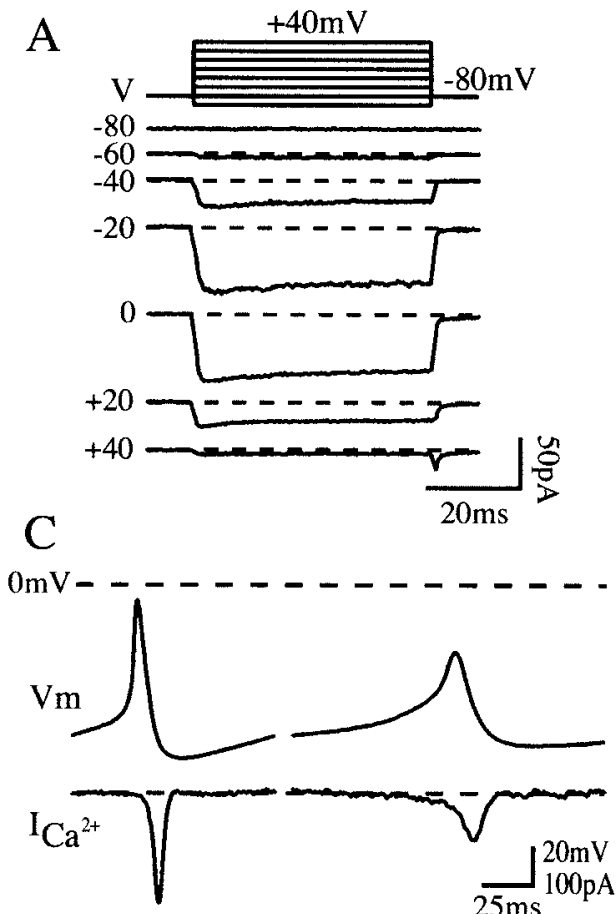

$\mathrm{E}$

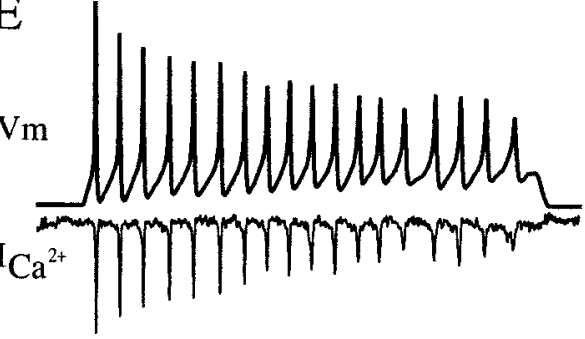

B

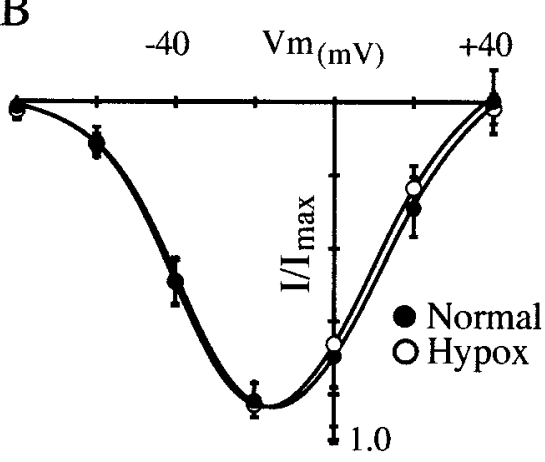

$\mathrm{D}$

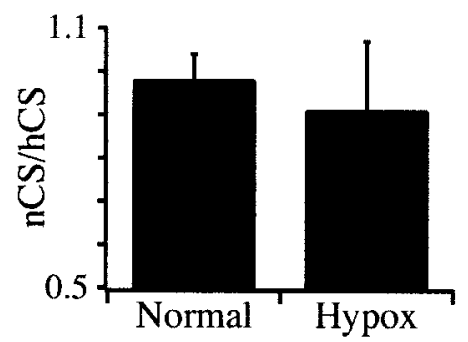

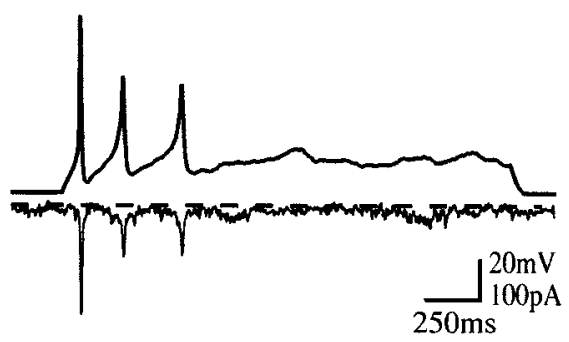

Figure 9. The calcium entry during sustained repetitive firing is likely to be more affected by spike frequency than by features of the action potential waveform. $A$, In hypox and normal rat chromaffin cells, calcium currents can be activated by repeated steps to increasingly positive voltages from -80 $\mathrm{mV}$. $B$, Normalized $I-V$ plots constructed by measuring peak inward currents activated during a series of positive voltage steps (like those in $A$ ) reveal only a minor difference in the average voltage of peak current activation for the normal and hypox rat cell populations $(n=5)$. $C$, APWs $($ voltage trace $)$ recorded previously from typical normal and hypox spike trains were presented to chromaffin cells in whole-cell voltage-clamp recording mode. Calcium currents were elicited by waveform clamp in both hypox and normal cells $(n=5)$. Total calcium influx was estimated by integrating the area between the baseline and the current trace. Calcium entry was quite similar in the two waveforms, with greater duration barely compensating for the stronger depolarization in the normal waveform. $D$, For normal and hypox cells, average calcium accumulations during the normal waveform, expressed as a fraction of that during the hypox waveform, were $0.98 \pm 0.06$ and $0.91 \pm 0.16$, respectively. $E$, Calcium entry elicited by presentation of normal (right) or hypox (left) AP spike trains in waveform clamp is shown. Calcium influx closely followed spike train frequency, suggesting that calcium influx is more likely influenced by repetitive firing than by features of the AP waveform.

greatly increases cytosolic calcium with important functional consequences for controlling the magnitude of epinephrine secretion.

The finding that whole-cell excitability and BK functional properties change in parallel supports the hypothesis that BK channels are a major determinant in shaping intrinsic excitability. Solaro et al. (1995) have suggested, on the basis of the heterogeneity in chromaffin cells, that differences in BK channel deactivation might be responsible for driving repetitive firing. Thus cells exhibiting slow BK deactivation tended to exhibit BK inactivation (i.e., were $\mathrm{BK}_{\mathrm{i}}$ cells), and $\mathrm{BK}_{\mathrm{i}}$ cells tended to have better repetitive firing during prolonged depolarization than did $\mathrm{BK}_{\mathrm{s}}$ cells. That BK channels can have a positive rather than a negative relationship to repetitive firing is further supported by evidence that BK channel blockade by $\mathrm{TEA}^{+}$or CTX can reduce or even eliminate recurrent firing (Fig. $8 A$ ) (see also Solaro et al., 1995). The results presented here suggest that several features of BK gating contribute to the improved repetitive firing observed in normal chromaffin cells. First, BK channels that open earlier (at more negative voltages) and more quickly will drive more rapid repolarization, thus minimizing entry of $\mathrm{Na}^{+}$and $\mathrm{Ca}^{2+}$ channels into an inactivated state. Second, slower deactivation will increase both the duration and magnitude of the spike AHP, facilitating deinactivation of inactivated $\mathrm{Na}^{+}$and $\mathrm{Ca}^{2+}$ channels. In this scenario, the tendency of $\mathrm{Na}^{+}$and $\mathrm{Ca}^{2+}$ channels to accumulate in an inactivated state comprises the primary limiting factor with respect to sustained firing, and BK currents represent perhaps the most important force counteracting this limitation. Modeling studies investigating the role of potassium channels as enhancers of repetitive firings argue that even an approximately $-20 \mathrm{mV}$ shift in half-activation can substantially improve sustained firing by driving spike repolarization and increasing AHP magnitude. In agreement with this view, the majority of normal cells, as compared with hypox cells studied in parallel, characteristically fired a greater number of spikes, the spikes exhibited a shorter 
half-amplitude duration, and the AHP was more pronounced. Moreover, the progressive decline in AP amplitude and increase in half-amplitude width associated with the accumulative loss of $\mathrm{Na}^{+}$and $\mathrm{Ca}^{2+}$ channels during sustained firing were more severe in hypox cells than in normal cells. Thus normal cells were better able to sustain spike amplitude and duration characteristics over an action potential train.

Together with the previous studies of Xie and McCobb (1998), the results suggest a molecular mechanism for pituitary control of chromaffin cell excitability. Xie and McCobb (1998) reported that hypophysectomy reduces the proportion of Slo transcripts including STREX, an effect prevented by injections of the pituitary hormone ACTH. Patches pulled from oocytes expressing homotetramers of STREX or ZERO revealed that the former were half-activated at more negative voltages and exhibited faster and slower activation and deactivation kinetics, respectively. The straightforward hypothesis was that hypox BK channels should appear more like oocyte-expressed Slo transcripts lacking STREX. This hypothesis is confirmed here. Interestingly, the 36 $\mathrm{mV}$ positive shift in the voltage of half-activation was greater than the difference between STREX and ZERO forms expressed separately (as homomultimers). One explanation for this observation is that native and oocyte environments somehow differentially accentuate the difference deriving from STREX inclusion. For example, in pituitary cells, a phosphorylation that impacts on the Slo voltage-dependent gating appears to depend on the presence of STREX (Shipston et al., 1999). At least five potential sites on STREX meet the consensus criteria for cGMP-dependent protein kinase and $\mathrm{PKC}$-mediated phosphorylation, two of which also satisfy the criteria for PKA phosphorylation (Saito et al., 1997). Perhaps unavailable in oocytes, such a secondary factor might, but need not necessarily, be subject to dynamic HPA regulation in native cells. Factors unrelated to STREX splicing that are subject to HPA control could also contribute to the differences we report here. As discussed further below, accessory subunits, particularly those in the $\beta$ family (McCobb et al., 1995; McManus et al., 1995; Dworetzky et al., 1996; Meera et al., 1996; Oberst et al., 1997; Saito et al., 1997; Jones et al., 1999a,b; Ramanathan et al., 1999; Wallner et al., 1999; Xia et al., 1999, 2000; Uebele et al., 2000), can have effects on activation and deactivation gating as well as on inactivation gating. Other candidate mechanisms include post-translational modulation. Despite possible contributions from unknown mechanism(s), hormonally driven changes in STREX splicing can account for a large part of the differences attributed to hypophysectomy.

With respect to activation and deactivation gating, BK currents in bovine chromaffin cells more closely resemble those of hypox rats than those of normal rats. Thus bovine currents are slower activating and faster deactivating and activate at more positive voltages than do normal rat BK currents. Importantly, the abundance of STREX relative to ZERO forms of Slo mRNA is much less in bovine than in normal rat adrenal medulla and more comparable with that in the hypox rat (Chatterjee et al., 1999) (our unpublished observations). This correlation supports the idea that differences at the STREX splice site account for functional differences in channel properties.

Hormones mediating pituitary control of chromaffin excitability are still under investigation. ACTH injection can prevent the decline in STREX that would otherwise result from pituitary ablation (Xie and McCobb, 1998). The precipitous drop in corticosterone that results from the loss of ACTH with hypophysectomy could act directly on STREX splicing. Although the impact on excitability is unknown, corticosteroids have been reported to increase $\mathrm{Kv} 1.5 \mathrm{~K}^{+}$channel transcription selectively in rat pituitary cells, ventricular myocytes, and skeletal muscle cells (Levitan and Takimoto, 1998). Plasma ACTH levels in rats have been measured at levels between 5 and 10 times those of bovine, and corticosterone levels in rats are nearly 10 -fold greater than levels of the predominant analog cortisol in cows (el-Nouty et al., 1978; Koehl et al., 1999; Manzanares et al., 1999; Veissier et al., 1999; Viau et al., 1999). Although circumstantial, these arguments raise the possibility that the HPA plays a role in both species-specific and dynamic regulation of chromaffin BK gating properties and excitability.

Interestingly, bovine currents also differ from those of normal rats in having inactivation that is much slower or incomplete. In this respect, currents in hypox rat cells do not resemble those in bovine. Inactivation is undoubtedly conferred by one or more members of the $\beta$ subunit gene family, although which are involved has not been established in chromaffin cells. Some but not all $\beta$ family members also may shift the voltage dependence of BK gating in artificial expression systems. The lack of change associated with hypophysectomy that we see in inactivation would suggest that major changes in $\beta$ subunit composition may not occur. The data suggest that regulation of inactivation is at least partially independent of the regulation of activation and deactivation gating.

Accompanying the drop in STREX abundance and BK functional changes resulting from hypophysectomy is a precipitous decline in the levels of the epinephrine-synthesizing enzyme PNMT in chromaffin cells (Xie and McCobb, 1998; see also Stachowiak et al., 1988; Viskupic et al., 1994). Bidirectional changes in PNMT mRNA and PNMT enzymatic activity can be driven by more subtle perturbations of glucocorticoid levels and by behavioral stress paradigms (Wong et al., 1992; Baruchin et al., 1993; Lemaire et al., 1993; Betito et al., 1994; Wong et al., 1995). Even brief exposure to intense stress and repeated exposure to milder stress can produce lasting changes (Lemaire et al., 1993; Betito et al., 1994). The link between stress and PNMT is further supported by the elucidation of glucocorticoid response element (GRE)-mediated regulation of PNMT transcription. The present studies suggest that changes in the epinephrine synthetic capacity of secreting cells may be accompanied by improved repetitive firing that functionally increases intracellular $\left[\mathrm{Ca}^{2+}\right]$ and enhances epinephrine secretion. It has long been recognized that the dynamics of the adrenal epinephrine response profoundly affects cardiovascular and respiratory function not only in crisis response situations but daily. Epinephrine responses thus contribute to complex positive and negative feedback regulation of brain, immune, metabolic, reproductive, and other functions. The present findings motivate further exploration of the possibility that chronic overactivation of the HPA produces a functional hypertrophy of chromaffin excitability that is potentially detrimental, perhaps elevating the risk of heart attack or stroke provoked by acute autonomic activation.

\section{APPENDIX}

The ionic currents described by Equation 2 can be written as:

$$
\begin{aligned}
I_{\text {ion }} & =g_{\mathrm{Na}}\left(V_{\mathrm{m}}-E_{\mathrm{Na}}\right)+g_{K}\left(V_{\mathrm{m}}-E_{\mathrm{K}}\right) \\
& =\bar{g}_{\mathrm{Na}} m^{3} h\left(V_{\mathrm{m}}-E_{\mathrm{Na}}\right)+\bar{g}_{K} n^{3}\left(V_{\mathrm{m}}-E_{\mathrm{K}}\right),
\end{aligned}
$$

where $g_{\text {ion }}$ is the maximum conductance for each ionic current, and $m, h$, and $n$ are time- and voltage-dependent rate constants 
(written as $\eta$ in the following equations) for the activation and inactivation rate constants. The time and voltage dependence of the rate constants is given by:

$$
\frac{\mathrm{d} \eta}{\mathrm{d} t}=\alpha_{\eta}-\left(a_{\eta}+b_{\eta}\right) \cdot \eta=\frac{\eta_{\infty}-\eta}{\tau_{\eta}}
$$

where:

$$
\begin{gathered}
\tau_{\eta}=\frac{1}{\alpha_{\eta}+\beta_{\eta}}, \\
\eta_{\infty}=\frac{\alpha_{\eta}}{\alpha_{\eta}+\beta_{\eta}} .
\end{gathered}
$$

The magnitude and time course of the activation and inactivation parameters used to describe the currents in Equation 2 are given below.

$$
\begin{gathered}
I_{\mathrm{Na}}: \\
I_{\mathrm{Na}}=g_{\max } m^{3} h\left(V_{\mathrm{m}}-E_{\mathrm{Na}}\right), \\
g_{\max }=20 \mathrm{mS} / \mathrm{cm}^{2} ; E_{\mathrm{Na}}=45 \mathrm{mV} . \\
m: \alpha=\frac{-4.5+0.1 \cdot V_{\mathrm{m}}}{-1+e^{\left(45+V_{\mathrm{m}}\right) /-10}}, \\
\beta=\frac{4}{e^{\left(70+V_{\mathrm{m})}\right) / 18}} . \\
h: \alpha=\frac{0.07}{e^{\left(70+V_{\mathrm{m}}\right) / 20}}, \\
\beta=\frac{1}{1+e^{\left(40+V_{\mathrm{m}}\right) / 20}} .
\end{gathered}
$$

$I_{\mathrm{Kv}} 20$ :

$$
\begin{gathered}
I_{\mathrm{Kv}} 20=g_{\max } m^{3}\left(V_{\mathrm{m}}-E_{\mathrm{K}}\right), \\
g_{\max }=700 \mathrm{mS} / \mathrm{cm}^{2}: E_{\mathrm{K}}=-85 \mathrm{mV} . \\
n_{20}: \alpha=\frac{0.026}{e^{-V_{\mathrm{m} /} / 45.27}}, \\
\beta=\frac{0.026}{e^{-\left(3.68+V_{\mathrm{m}}\right) / 27.22}} .
\end{gathered}
$$

$I_{\mathrm{Kv}} 40$ :

$$
\begin{gathered}
I_{\mathrm{Kv}} 40=g_{\max } m^{3}\left(V_{\mathrm{m}}-E_{\mathrm{K}}\right), \\
g_{\max }=700 \mathrm{mS} / \mathrm{cm}^{2} ; E_{\mathrm{K}}=-85 \mathrm{mV} . \\
n_{40}: \alpha=\frac{0.014}{e^{-V_{\mathrm{m} /} / 25.88}}, \\
\beta=\frac{0.014}{e^{-\left(-54.78+V_{\mathrm{m}}\right) / 43.29}} .
\end{gathered}
$$

\section{REFERENCES}

Artalejo CR, Adams ME, Fox AP (1994) Three types of $\mathrm{Ca}^{2+}$ channel trigger secretion with different efficacies in chromaffin cells. Nature 367:72-76.
Baruchin A, Vollmer RR, Miner LL, Sell SL, Stricker EM, Kaplan BB (1993) Cold-induced increases in phenylethanolamine $N$-methyltransferase (PNMT) mRNA are mediated by non-cholinergic mechanisms in the rat adrenal gland. Neurochem Res 18:759-766.

Betito K, Diorio J, Meaney MJ, Boksa P (1992) Adrenal phenylethanolamine $N$-methyltransferase induction in relation to glucocorticoid receptor dynamics evidence that acute exposure to high cortisol levels is sufficient to induce the enzyme. J Neurochem 58:1853-1862.

Betito K, Mitchell JB, Bhatnagar S, Boksa P, Meaney MJ (1994) Regulation of the adrenomedullary catecholaminergic system after mild, acute stress. Am J Physiol 267:R212-R220.

Chatterjee S, Lai G, Lovell PV, McDonald TJ, Nathanielsz PW, McCobb DP (1999) Cows, rats, and baboons: big differences in "Slo" $\mathrm{K}^{+}$channel splicing in adrenal chromaffin cells. Soc Neurosci Abstr 25:348.

De Schutter E (1989) Computer software for development and simulation of compartmental models of neurons. Comput Biol Med 19:71-81.

Ding JP, Li ZW, Lingle CJ (1998) Inactivating BK channels in rat chromaffin cells may arise from heteromultimeric assembly of distinct inactivation-competent and noninactivating subunits. Biophys $\mathrm{J}$ 74:268-289.

Dworetzky SI, Boissard CG, Lum-Ragan JT, McKay MC, Post-Munson DJ, Trojnacki JT, Chang C-P, Gribkoff VK (1996) Phenotypic alteration of a human BK (hslo) channel by hslo $\beta$ subunit coexpression: changes in blocker sensitivity, activation/relaxation and inactivation kinetics, and protein kinase A modulation. J Neurosci 16:4543-4550.

Elhamdani A, Zhou Z, Artalejo CR (1998) Timing of dense-core vesicles exocytosis depends on the facilitation L-type Ca channel in adrenal chromaffin cells. J Neurosci 18:6230-6240.

el-Nouty FD, Elbanna IM, Johnson HD (1978) Effect of adrenocorticotropic hormone on plasma glucocorticoids and antidiuretic hormone of cattle exposed to 20 and $33 C^{\circ}$. J Dairy Sci 61:189-196.

Evinger MJ, Towle AC, Park DH, Lee P, Joh TH (1992) Glucocorticoids stimulate transcription of the rat phenylethanolamine $N$-methyltransferase (PNMT) gene in vivo and in vitro. Cell Mol Neurobiol 12:193-215.

Forsythe GE, Malcolm MA, Moler CB (1977) Computer methods for mathematical computations, pp 110-147. Englewood Cliffs, NJ: Prentice-Hall.

Hamill OP, Marty A, Neher E, Sakmann B, Sigworth FJ (1981) Improved patch-clamp techniques for high-solution current recording from cells and cell-free membrane patches. Pflügers Arch 391:85-100.

Herrington J, Solaro CR, Neely A, Lingle CJ (1995) The suppression of $\mathrm{Ca}^{2+}$ - and voltage-dependent outward $\mathrm{K}^{+}$current during $\mathrm{mAChR}$ activation in rat adrenal chromaffin cells. J Physiol (Lond) 485:297-318.

Hodgkin AL, Huxley AF (1952) A quantitative description of membrane current and its application to conduction and excitation in nerve. J Physiol (Lond) 117:500-544.

Jones EM, Gray-Keller M, Art JJ, Fettiplace R (1999a) The functional role of alternative splicing of $\mathrm{Ca}^{2+}$-activated $\mathrm{K}^{+}$channels in auditory hair cells. Ann NY Acad Sci 868:379-385.

Jones EM, Gray-Keller M, Fettiplace R (1999b) The role of $\mathrm{Ca}^{2+}$ activated $\mathrm{K}^{+}$channel spliced variants in the tonotopic organization of the turtle cochlea. J Physiol (Lond) 518:653-656.

Koehl M, Darnaudery M, Dulluc J, Van Reeth O, Le Moal M, Maccari S (1999) Prenatal stress alters circadian activity of hypothalamopituitary-adrenal axis and hippocampal corticosteroid receptors in adult rats of both gender. J Neurobiol 40:302-315.

Lemaire V, Le Moal M, Mormede P (1993) Regulation of catecholamine-synthesizing enzymes in adrenals of Wistar rats under chronic stress. Am J Physiol 264:R957-R962.

Levitan ES, Takimoto K (1998) Dynamic regulation of $\mathrm{K}^{+}$channel gene expression in differentiated cells. J Neurobiol 37:60-68.

Lingle CJ, Solaro CR, Prakriya M, Ding JP (1996) Calcium-activated potassium channels in adrenal chromaffin cells. In: Ion channels (Narahashi T, ed), pp 261-301. New York: Plenum.

López MG, Villarroya M, Lara B, Sierra RM, Albillos A, García G, Gandía L (1994) Q- and L-type $\mathrm{Ca}^{2+}$ channels dominate the control of secretion in bovine chromaffin cells. FEBS Lett 349:331-337.

Lovell PV, James DG, McCobb DP (2000) Bovine verses rat adrenal chromaffin cells: big differences in BK potassium channel properties. J Neurophysiol 83:3277-3286.

Manzanares J, Corchero J, Fuentes JA (1999) Opioid and cannabinoid receptor-mediated regulation of the increase in adrenocorticotropin hormone and corticosterone plasma concentrations induced by central administration of delta(9)-tetrahydrocannabinol in rats. Brain Res 839:173-179.

McCobb DP, Fowler NL, Featherstone T, Lingle CJ, Saito M (1995) A human calcium-activated potassium channel gene expressed in vascular smooth muscle. Am J Physiol 269:767-777.

McManus OB, Helms LMH, Pallanck L, Ganetsky B, Swanson R, Leonard RJ (1995) Functional role of the $\beta$-subunit of high-conductance calcium-activated potassium channels. Neuron 14:645-650.

Meera P, Wallner M, Jiang Z, Toro L (1996) A calcium switch for the functional coupling between $\alpha$ (hslo) and $\beta$ subunits $\left(\mathrm{K}_{\mathrm{v}},{ }_{\mathrm{Ca}} \beta\right)$ of maxi K channels. FEBS Lett 382:84-88. 
Neely A, Lingle CJ (1992a) Two components of calcium-activated potassium current in rat adrenal chromaffin cells. J Physiol (Lond) 453:97-131.

Neely A, Lingle CJ (1992b) Effects of muscarine on single rat adrenal chromaffin cells. J Physiol (Lond) 453:133-166.

Oberst C, Weiskirchen R, Hartl M, Bister K (1997) Suppression in transformed avian fibroblasts of a gene (CO6) encoding a membrane protein related to a mammalian potassium channel regulatory protein. Oncogene 14:1109-1116.

Ramanathan K, Michael TH, Jiang G, Hiel H, Fuchs PA (1999) A molecular mechanism for electrical tuning of cochlear hair cells. Science 283:215-217.

Ross ME, Evinger MJ, Hyman SE, Carroll JM, Mucke L, Comb M, Reis DJ, Joh TH, Goodman HM (1990) Identification of a functional glucocorticoid response element in the phenylethanolamine- $N$ methyltransferase promoter using fusion genes introduced into chromaffin cells in primary culture. J Neurosci 10:520-530.

Saito M, Nelson C, Salkoff L, Lingle CJ (1997) A cysteine-rich domain defined by a novel exon in a slo variant in rat adrenal chromaffin cells and PC12 cells. J Biol Chem 18:11710-11717.

Sakmann B, Neher E (1985) Single-channel recording, 2nd edition. New York: Plenum.

Shao LR, Halvorsrud R, Borg-Graham L, Storm JF (1999) The role of BK-type $\mathrm{Ca}^{2+}$-dependent $\mathrm{K}^{+}$channels in spike broadening during repetitive firing in rat hippocampal pyramidal cells. J Physiol (Lond) 521:135-146.

Shipston MJ, Duncan RR, Clark AG, Antoni FA, Tian J (1999) Molecular components of large conductance calcium-activated potassium (BK) channels in mouse corticotropes. Mol Endocrinol 13:1728-1737.

Solaro CR, Prakriya M, Ding JP, Lingle CJ (1995) Inactivating and noninactivating $\mathrm{Ca}^{2+}$-and voltage-dependent $\mathrm{K}^{+}$current in rat adrenal chromaffin cells. J Neurosci 15:6110-6123.

Stachowiak MK, Rigual RJ, Lee PHK, Viveros OH, Hong JS (1988) Regulation of tyrosine hydroxylase and phenylethanolamine $N$-methyltransferase mRNA levels in the sympathoadrenal system by the pituitary-adrenocortical axis. Brain Res Mol Brain Res 3:275-286.

Uebele VN, Lagrutta A, Wade T, Figueroa DJ, Liu Y, McKenna E, Austin CP, Bennett PB, Swanson R (2000) Cloning and functional expression of 2 families of $\beta$-subunits of the large conductance calciumactivated $\mathrm{K}^{+}$channel. J Biol Chem 275:23211-23218.

Veissier I, van Reenen CG, Andanson S, Leushuis IE (1999) Adrenocorticotropic hormone and cortisol in calves after corticotropinreleasing hormone. J Anim Sci 77:2047-2053.

Viau V, Chu A, Soriano L, Dallman MF (1999) Independent and overlapping effects of corticosterone and testosterone on corticotropinreleasing hormone and arginine vasopressin mRNA expression in the paraventricular nucleus of the hypothalamus and stress-induced adrenocorticotropic hormone release. J Neurosci 19:6684-6693.

Viskupic E, Kvetnansky R, Sabban EL, Fukuhara K, Weise VK, Kopin IJ, Schwartz JP (1994) Increase in rat adrenal phenylethanolamine $N$-methyltransferase mRNA level caused by immobilization stress depends on intact pituitary-adrenocortical axis. J Neurochem 63:808-814.

Wallner M, Meera P, Toro L (1999) Molecular basis of fast inactivation in voltage and $\mathrm{Ca}^{2+}$-activated $\mathrm{K}^{+}$channels: a transmembrane $\beta$-subunit homolog. Proc Natl Acad Sci USA 96:4137-4142.

Wong DL, Lesage A, Siddall B, Funder JW (1992) Glucocorticoid regulation of phenylethanolamine $N$-methyltransferase in vivo. FASEB J 14:3310-3315.

Wong DL, Siddall B, Wang W (1995) Hormonal control of rat adrenal phenylethanolamine $N$-methyltransferase. Neuropsychopharmacology $13: 224-234$.

Wu YC, Fettiplace R (1996) A developmental model for generating frequency maps in the reptilian and avian cochleas. Biophys $\mathrm{J}$ 70:2557-2570.

Xia X-M, Ding JP, Lingle CJ (1999) Molecular basis for the inactivation of $\mathrm{Ca}^{2+}$ - and voltage-dependent BK channels in adrenal chromaffin cells and rat insulinoma tumor cells. J Neurosci 19:5255-5264.

Xia XM, Ding JP, Zeng XH, Duan KL, Lingle CJ (2000) Rectification and rapid activation at low $\mathrm{Ca}^{2+}$ of $\mathrm{Ca}^{2+}$-activated, voltage-dependent BK currents: consequences of rapid inactivation by a novel $\beta$ subunit. J Neurosci 20:4890-4903.

Xie J, McCobb DP (1998) Control of alternative splicing of potassium channels by stress hormones. Science 280:443-446.

Zhou Z, Misler S (1995) Action potential-induced quantal secretion of catecholamines from rat adrenal chromaffin cells. J Biol Chem 270:3498-3505. , 